\title{
CDOM Optical Properties and DOC Content in the Largest Mixing Zones of the Siberian Shelf Seas
}

\author{
Anastasia N. Drozdova ${ }^{1, *(\mathbb{C})}$, Andrey A. Nedospasov ${ }^{1}$, Nikolay V. Lobus ${ }^{2}$, Svetlana V. Patsaeva ${ }^{3} \mathbb{C}$ \\ and Sergey A. Shchuka ${ }^{1}$ \\ 1 Shirshov Institute of Oceanology, Russian Academy of Sciences, 117997 Moscow, Russia; \\ nedospasov.aa@ocean.ru (A.A.N.); shchuka@ocean.ru (S.A.S.) \\ 2 K.A. Timiryazev Institute of Plant Physiology, Russian Academy of Sciences, 127276 Moscow, Russia; \\ lobus.nv@ocean.ru \\ 3 Department of Physics, Lomonosov Moscow State University, 119234 Moscow, Russia; \\ patsaeva@physics.msu.ru \\ * Correspondence: adrozdova@ocean.ru
}

Citation: Drozdova, A.N.;

Nedospasov, A.A.; Lobus, N.V.;

Patsaeva, S.V.; Shchuka, S.A. CDOM Optical Properties and DOC Content in the Largest Mixing Zones of the Siberian Shelf Seas. Remote Sens. 2021, 13, 1145. https://doi.org/10.3390/ rs13061145

Academic Editor: Giacomo De Carolis

Received: 26 January 2021

Accepted: 14 March 2021

Published: 17 March 2021

Publisher's Note: MDPI stays neutral with regard to jurisdictional claims in published maps and institutional affiliations.

Copyright: (c) 2021 by the authors. Licensee MDPI, Basel, Switzerland. This article is an open access article distributed under the terms and conditions of the Creative Commons Attribution (CC BY) license (https:/ / creativecommons.org/licenses/by/ $4.0 /)$.
Abstract: Notable changes in the Arctic ecosystem driven by increased atmospheric temperature and ice cover reduction were observed in the last decades. Ongoing environmental shifts affect freshwater discharge to the Arctic Ocean, and alter Arctic land-ocean fluxes. The monitoring of DOC distribution and CDOM optical properties is of great interest both from the point of view of validation of remote sensing models, and for studying organic carbon transformation and dynamics. In this study we report the DOC concentrations and CDOM optical characteristics in the mixing zones of the $\mathrm{Ob}$, Yenisei, Khatanga, Lena, Kolyma, and Indigirka rivers. Water sampling was performed in August-October 2015 and 2017. The DOC was determined by high-temperature combustion, and absorption coefficients and spectroscopic indices were calculated using the seawater absorbance obtained with spectrophotometric measurements. Kara and Laptev mixing zones were characterized by conservative DOC behavior, while the East Siberian sea waters showed nonconservative DOC distribution. Dominant DOM sources are discussed. The absorption coefficient $a_{\mathrm{CDOM}}(350)$ in the East Siberian Sea was two-fold lower compared to Kara and Laptev seawaters. For the first time we report the DOC content in the Khatanga River of $802.6 \mu \mathrm{M}$ based on the DOC in the Khatanga estuary.

Keywords: CDOM absorbance; spectroscopic indices; DOC; Arctic; shelf seas; estuarial and coastal areas

\section{Introduction}

The oceanic dissolved organic matter (DOM) pool is one of Earth's large organic carbon reservoirs [1], and, therefore, represents an important component of marine ecosystems and the carbon cycle [2]. The main sources of DOM in the world ocean are primary production of phytoplankton and ice algae, as well as the secondary production of zooplankton. Additional DOM sources include more refractory, compared to the autochthonous material, terrestrial-derived DOM supplied by river runoff (more than $80 \%$ of terrigenous DOM), aeolian dust, and coastal abrasion [3].

The Arctic Ocean represents a unique ecosystem, which, on the one hand, is highly sensitive to climate changes occurring during previous decades, and on another, is an important feedback component of the global climate system [4]. An essential feature of the Arctic region is its exposure to large river discharge. Representing only $1 \%$ of the global ocean volume, the Arctic Ocean receives more than $10 \%$ of the global freshwater and, therefore, the vast amounts of riverine DOM [5,6]. This is a key factor in regulating biogeochemical cycles in the area. In estuarine and coastal zones, fresh waters and terrestrial material control the distribution of flora and fauna, their productivity, and consumption [7]. Here, the limitation of photosynthetic activity due to humic substances, absorbing sunlight in the blue spectral range, where chlorophyll and photosynthetic carotenoids have 
absorption maxima [8], is the most significant. Conversely, humic substances absorb in the UVB (280-320 nm) and/or UVA (320-400 nm) ranges [9], diminishing the negative effects of ultraviolet radiation on plankton populations [10]. High concentrations of terrigenous colored DOM (CDOM) rich in humic substances have a significant impact on penetration of light into the water column [11], water color, and its spectral features (see [12] and references therein). Thus, humic substances providing an essential component of the remotely sensed optical signal, affect estimates of chlorophyll concentration using satellite imagery [13-15] or shipborne lidar measurements [16,17].

Numerous studies have contributed to understanding biogeochemical cycling of organic carbon in the Arctic Ocean, see, for example, the PANGAEA database (https: / /www.pangaea.de/, accessed on 15 March 2021), the monographs and reviews [18-21], etc. At the same time, seasonal variability of DOC distribution is not quite clear: significant changes, often comparable with multiyear variations, may occur on time scales of a few weeks [19], while most sampling expeditions are restricted to a few months during summer. Thus, for example, Dai et al. [22] estimated the uncertainty of global river DOC discharge to the coastal seas as 30\%. Climate change in the Arctic [23-26] has already resulted in reduced ice cover and increased flows of terrigenous DOM due to permafrost thawing and coastal erosion. These changes require monitoring of the concentration and quality of DOM [27] to better understand the Arctic ecosystem and its response to changing conditions and anthropogenic stress. The development of forecasting models for predicting river export of DOM also involves the acquisition of new field data. Thus, a great need for additional DOC data, which can only be obtained in the field, was emphasized by Harrison et al. [28]. Taking into account the recent progress in development of quantitative CDOM and DOC determination with the use of satellite remote sensing [29,30], new field studies of DOC and optical properties of natural waters might be useful for validation of remote sensing models, as well as regional algorithms for estimation of absorption coefficient of colored organic matter [31].

In this paper, we present new data on the content of DOC in the Kara, Laptev, and East Siberian seas obtained during expeditions in summer and fall of 2015 and 2017. We analyze the data on the optical characteristics of the colored DOM fraction [32] to reveal its quality and the sources of DOM input. For the first time, we present DOM concentration at the section from the mixing zone of the Khatanga River to the continental slope obtained with the high temperature combustion technique, which allowed us to estimate the content of DOC in the Khatanga River. In previous studies (see, for example, the paper of Wheeler at al. [33]), the content of DOC in the Khatanga River was evaluated on the basis of total organic carbon concentration $(\mathrm{TOC}$ ) and the ratio $\mathrm{DOC} / \mathrm{TOC}=0.9$, typical for the Russian rivers [34].

\section{Materials and Methods}

2.1. Sampling

Samples were collected during the 63rd (28 August-6 October 2015) and 69th (22 August-26 September 2017) cruises aboard the R/V Akademik Mstislav Keldysh (Figure 1). Exact sampling dates for each sample are given in Supplementary Table S1. In 2015, the sampling was performed along a cross-slope transect in the Laptev Sea, starting from the Lena River Delta region (station 5216) and moving along the $130^{\circ} \mathrm{E}$ towards the continental slope. Absorbance was measured spectrophotometrically for five surface water samples, and DOC concentration was determined in 36 water samples from different depths. In 2017, 141 samples for DOC and 135 ones for absorbance were taken in the Kara, Laptev and East Siberian seas. We consider four shelf-crossing transects from the mixing zones of the Lena, Khatanga, Indigirka, and Kolyma rivers, as well as individual sampling sites in the Kara and Laptev seas. In the Kara Sea, the samples were collected in the estuarine zone of the $\mathrm{Ob}$ and Yenisei rivers (station 5588), in the central part of the Kara Sea to the north of Novaya Zemlya Trough (station 5587), and in the Blagopoluchiya Bay (the entrance-5641_2 and inner part of the bay water area-5642). One more station (5586) was 
located close to Novaya Zemlya Trough. In previous years, this region was characterized as less affected by $\mathrm{Ob}$ and Yenisei riverine waters [35].

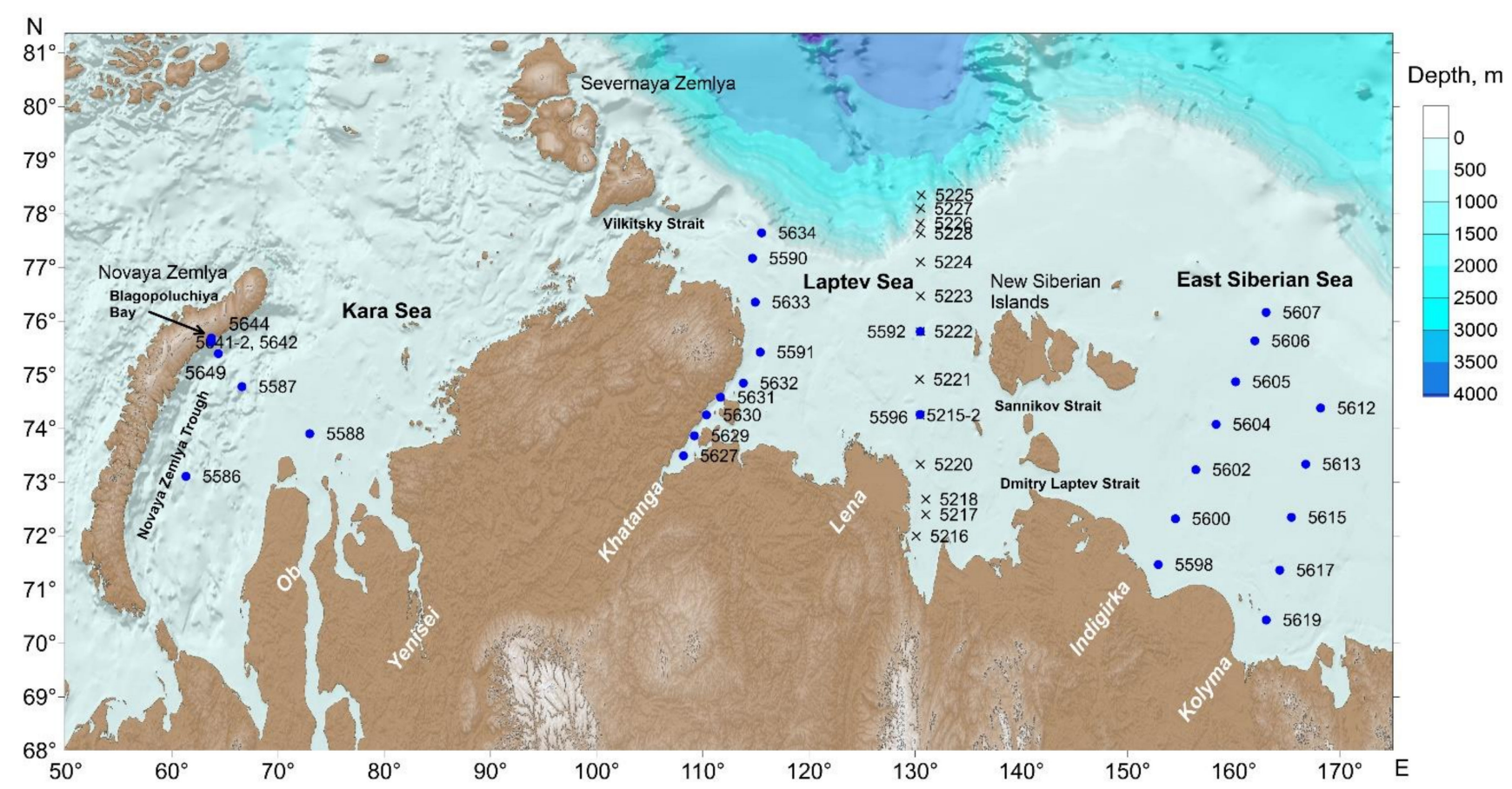

Figure 1. Sample site locations during the 63rd (black crosses) and 69th (blue dots) cruises of the R/V Akademik Mstislav Keldysh. The data from the study of Amante et al. [36] were used for the map plotting.

Water samples were taken using Niskin bottles of $5 \mathrm{~L}$ volume mounted on the $\mathrm{CTD} /$ rosette system at surface and discrete depths, associated with boundaries of large gradients of hydro-physical parameters. All the samples were filtered through precombustion at $450{ }^{\circ} \mathrm{C}$ Whatman GF/F filters with a nominal pore size of $0.7 \mu \mathrm{m}$. The filtrate was collected into the acid-cleaned $10 \mathrm{~mL}$ glass vials and stored under dark conditions at $4{ }^{\circ} \mathrm{C}$ until further analysis. For the DOC measurements, the filtrate was acidified up to $\mathrm{pH}=2$ before storage. Water temperature and practical salinity were derived from CTD measurements.

\subsection{Flow Measurements}

During the 69th cruise, we performed continuous observations of conductivity and temperature of subsurface water layer at $2.7 \mathrm{~m}$ depth. The measurements were carried out with a temporal resolution of $3 \mathrm{~s}$ (at a speed of 10 knots- $15 \mathrm{~m}$ ) using a SBE 21 SeaCAT Thermosalinograph (Sea-Bird Scientific) and a pump to supply outboard water.

\section{3. $D O C$}

DOC concentration was measured onshore by high-temperature combustion with a Shimadzu TOC-VCPH/CPN analyzer. Precision and accuracy of our measurements were determined relative to external laboratory standards, namely solutions of potassium hydrogen phthalate and sodium hydrogen carbonate diluted to different concentrations according to estimated DOC content, and amounted to $\pm 5 \%$ and $1 \%$, respectively.

\subsection{Optical Measurements and Spectroscopic Indices}

Absorbance $\mathrm{A}(\lambda)$ of water samples have been registered in the laboratory conditions at room temperature $22 \pm 2{ }^{\circ} \mathrm{C}$. Measurements were performed within the spectral range from $200-700 \mathrm{~nm}$ at $1 \mathrm{~nm}$ increments using double-beam scanning spectrophotometer Solar PB2201 with 3 or $5 \mathrm{~cm}$ quartz cuvettes depending on the DOC concentration and 
Milli-Q water as a blank. CDOM absorbance spectra are available online as supplementary information to the study of Drozdova et al. [32]. The blank-corrected absorbance spectra were converted into the Napierian absorption coefficients $a_{\mathrm{CDOM}}(\lambda)$ by multiplying CDOM absorbance by 2.303 and dividing by the cuvette path length taken in meters. In accordance with the study of Helms et al. [37], the spectral slope for the 275-295 nm range $\left(S_{275-295}\right)$ and the ratio of $S_{275-295}$ and $S_{350-400}\left(S_{R}\right)$ were determined using linear regression of the log-transformed functions of absorption coefficients $a_{\mathrm{CDOM}}(\lambda)$ defined as:

$$
a_{C D O M}(\lambda)=a_{C D O M}\left(\lambda_{0}\right) e^{-S\left(\lambda-\lambda_{0}\right)}
$$

where $\lambda_{0}$ is a reference wavelength [38]. $S_{R}$ index was reported by Helms et al. [37] to correlate with molecular weight and the degree of photochemical degradation of CDOM. Thus, $S_{R}<1$ is typical for terrestrial CDOM, while $S_{R}>1.5$ indicate the presence of oceanic and photodegraded terrestrial CDOM, see also [12,39]. The value of $S_{275-295}$ is also used for the CDOM source discrimination so that $S_{275-295}>20$ is typical for marine waters, while $\mathrm{S}_{275-295}<16$ is a characteristic of riverine waters. A specific UV absorbance (SUVA) was calculated by normalizing the decadic absorption at $254 \mathrm{~nm}$ to the DOC concentration in milligrams per liter $(\mathrm{mg} / \mathrm{L})$. It was shown to be a useful parameter for estimating the dissolved aromatic carbon content in aquatic systems [40]. The value of SUVA $<1.8$ is an evidence of algae and bacteria CDOM predominance, and SUVA $>3$ suggests the terrestrial CDOM origin. Spectroscopic indices are given in our recent studies [32,41].

\section{Results}

\subsection{Subsurface Water Temperature and Salinity}

At the end of August 2017, an influx of warm and salty waters that originated from the Barents Sea, was recorded in the Kara Sea (Figure 2). The eastern type of freshened water distribution [42] was observed in the Kara Sea at the beginning of the cruise. It is characterized by the transfer of low-salinity waters, formed under the influence of $\mathrm{Ob}$ and Yenisei river runoff, along the coast towards the Wilkitsky Strait. To the east of $94^{\circ} \mathrm{E}$ and up to the Laptev Sea, the drifting ice was constantly met, therefore, the thermosalinograph was switched off. On the way back, ice did not occur, but in the northern part (north of $76^{\circ} \mathrm{N}$ ), the subsurface temperature was still below zero. Freshened waters were shifted westward a month later, which is typical for the central type of freshened water distribution.

In the northwestern part of the Laptev Sea, to the east of the Vilkitsky Strait, surface water temperature was below zero (Figure 2). The highest values of about $5{ }^{\circ} \mathrm{C}$ were observed for the freshened waters formed under the influence of the Lena River discharge. On the way back, the temperature and salinity distribution in the central and eastern parts of the Laptev Sea did not change significantly. In the northeast, the temperature dropped by $1-1.5^{\circ} \mathrm{C}$ and negative water temperature values were observed between the station 5634 and the Vilkitsky Strait.

According to the thermosalinograph data, the water temperature of the subsurface layer in the East Siberian Sea decreased from south to north (Figure 2). Negative values were observed near the ice massif, the edge of which was located above the $70 \mathrm{~m}$ isobath. Water freshening was observed in the shelf region. At the transect from the Kolyma River estuary to the continental slope, a pronounced frontal zone to the south of station 5615 was observed. Salinity did not change significantly to the north, while to the south it dropped sharply from 28 to 17 within $125 \mathrm{~km}$ distance. On the contrary, no large horizontal gradients were observed in the Indigirka section. Similar to the Laptev Sea, the distribution of river waters reaches an isobath of $25 \mathrm{~m}$. 

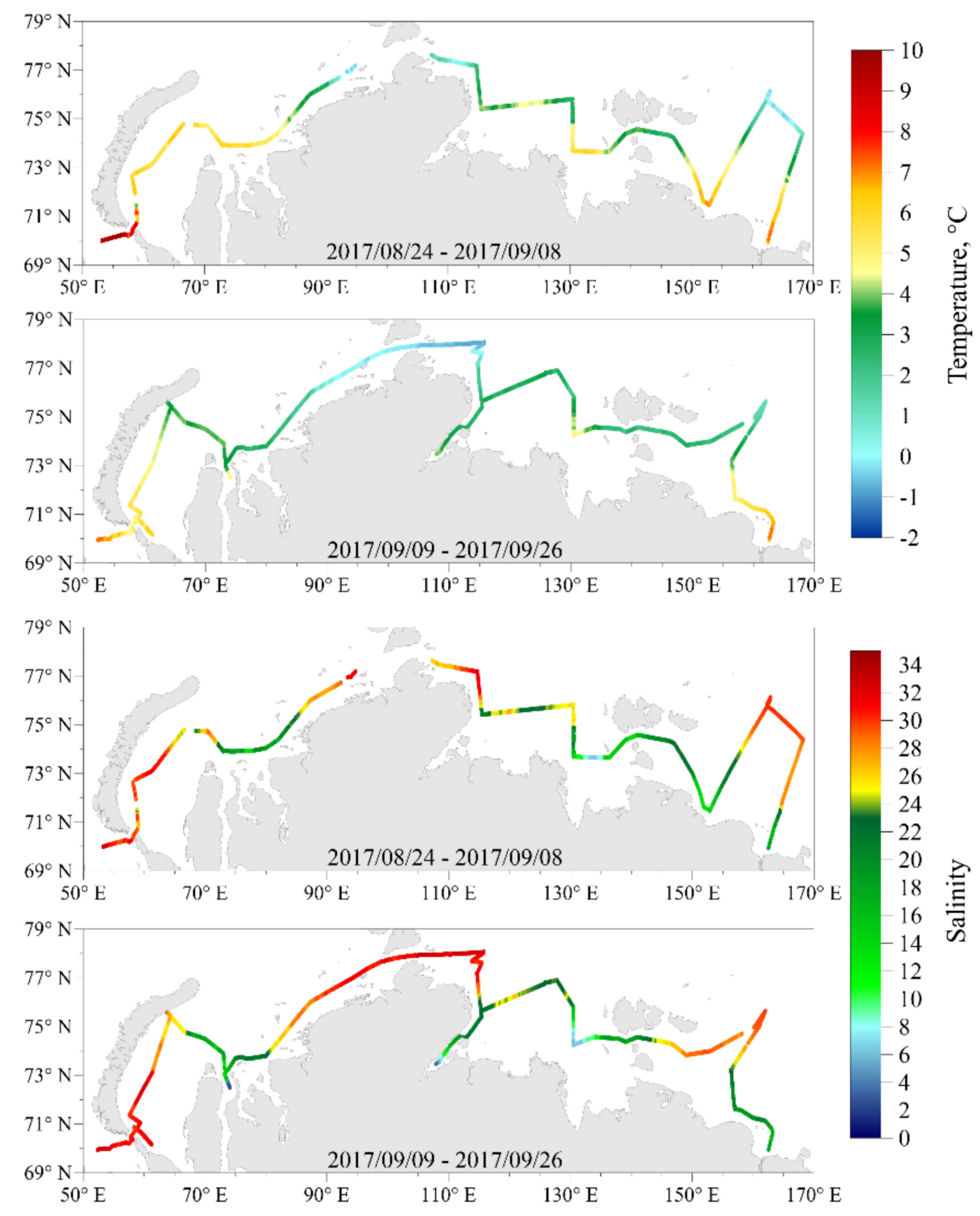

Figure 2. Water temperature and salinity at the depth of $2.7 \mathrm{~m}$ (thermosalinograph data) along the route of the 69th cruise of the R/V Akademik Mstislav Keldysh in the Kara, Laptev and East-Siberian seas.

\subsection{Vertical Sensing of Hydrophysical Parameters}

\subsubsection{Kara Sea}

In the first part of the cruise, the surface waters of the Kara Sea warmed up to 2.5$5.5^{\circ} \mathrm{C}$ (Figure 3). With the exception of the stations located in the Blagopoluchiya Bay $(5642,5641$, and 5644), a pronounced cold intermediate layer (CIL), formed during winter convection, was observed. 


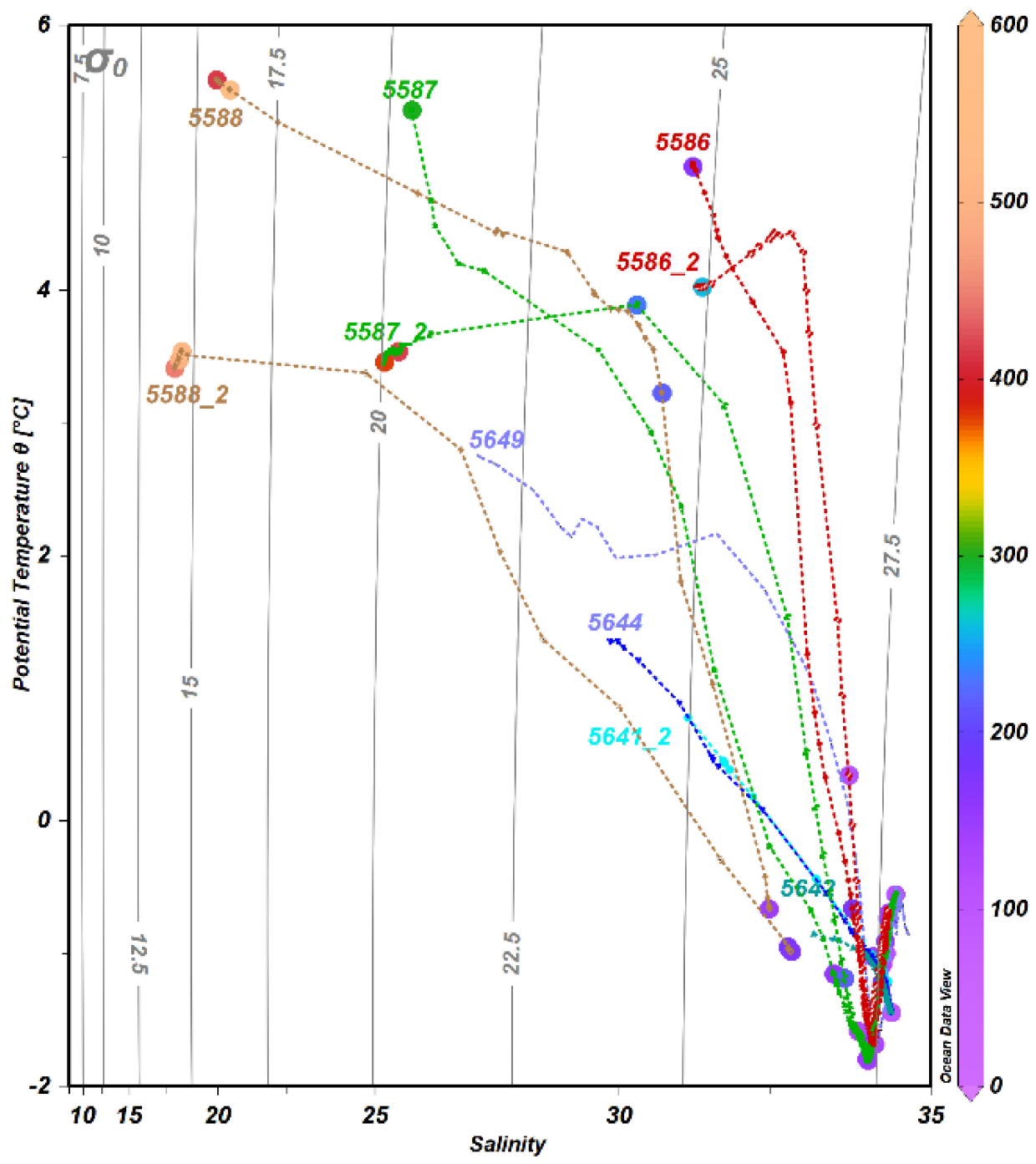

Figure 3. Temperature—salinity diagram for CTD profiles observed in the Kara Sea in Autumn, 2017. Color coding indicates DOC concentration $(\mu \mathrm{M})$.

The core of CIL was located at depths of about $50 \mathrm{~m}$. This agrees well with the data reported by Pavlov and Pfirman [42], who states that summer warming extends to depths of 20-60 m. The upper heated layer thickness in different areas varied from $5 \mathrm{~m}$ at station 5641 to $25 \mathrm{~m}$ at the Ob-Yenisei coast (5588), and was absent completely in the inner part of Blagopoluchiya Bay (5642). It was reported previously that the depth of the surface layer in the Kara Sea was 6-8 $\mathrm{m}$ in shallow parts of the sea, ranging up to $20-30 \mathrm{~m}$ over deeper regions [42]. Under the CIL core, the temperature profiles were quite different. The increase of temperature with depth in the south (5586) is much sharper than the one in the northern part of the Novaya Zemlya basin $(5587,5649)$. In the Novaya Zemlya Trough at depths above $120 \mathrm{~m}$, we suggest the active admixing of waters, which flow from the Barents Sea along the St. Anna Trough. A month later (stations 5586_2, 5587_2, and 5588_2), the surface water temperature dropped by $1-2{ }^{\circ} \mathrm{C}$. The remaining profiles have changed insignificantly (Figure 3). Salinity in the studied areas of the Kara Sea varied from 20, measured for the Ob-Yenisei coast surface waters, to 34.6 (deep waters). Below $50 \mathrm{~m}$, all profiles are similar, except for the station 5587, which is characterized by fresher deep waters. High salinity $>31$ was measured in the Bay and at the southern station 5586, where the waters of the $\mathrm{Ob}$ and Yenisei did not extend. The influence of $\mathrm{Ob}$ and/or Yenisei riverine waters was reported in 2015 in the Oga and Tsivol'ki Bays of the Severny Island of Novaya Zemlya [35,43], when the western distribution of low-salinity waters [44] was observed. The temperature in the 
CIL core at station 5587 was $-1.8^{\circ} \mathrm{C}$. This roughly corresponds to the freezing point of water with a salinity of 32.8 . Taking into account that the formation of CIL is related to vertical mixing during the winter period, we suggest that the salinity in the upper layer of the Kara Sea in winter is quite high-above 32. The waters with lower salinities distributed in the Kara Sea in the summer and fall periods is the result of current-year freshening caused by the $\mathrm{Ob}$ and Yenisei rivers, the Baydaratskaya Bay, and melt waters. In the study of Olsson and Anderson [45], such a threshold salinity value in case of the Siberian shelf seas was reported to be 24 .

\subsubsection{Laptev Sea}

Along the transects in the Lena Delta region, water was warmed up to 10-15 m (Figure 4). Closer to the coastline, the temperature of the low-salinity water layer was $5{ }^{\circ} \mathrm{C}$ and decreased to $1-2{ }^{\circ} \mathrm{C}$ away from the Lena Delta region. The bottom water layer was characterized by temperatures below zero. The mixing of riverine and sea waters occurred throughout the entire water column of $20 \mathrm{~m}$ depth in the southern part of the sections. Compared to 2015, the spreading of freshened waters along the transect was weaker. In 2015 , the salinity value of 25 was observed $200 \mathrm{~km}$ farther to the north. The waters in the area of the shallow shelf were freshened up to the $20 \mathrm{~m}$ depth. A frontal zone was observed above the sloping shelf brow at about $20 \mathrm{~m}$ depth, were the waters with salinity of 15 or less were distributed. In opposite, salinity of 15 was measured $50 \mathrm{~km}$ southerly in 2015 (Figure 4). We assume that a more active horizontal mixing of sea and river waters took place in 2015. Consequently, low-salinity waters spread far to the north, but at the same time low salinity values were observed closer to the Lena Delta. The halocline was located at depths of 10-15 m along the entire transect, and isohaline concentration within the frontal zone increased above the brow of the slope. This result does not completely support a schematic diagram of the interactions occurring in the Laptev Sea continental shelf close to the Lena River delta region reported by Gonçalves-Araujo et al. [46], since it implied reducing the thickness of plume-influenced freshened water layer, but agrees well with the data on salinity and temperature vertical distribution along the $130^{\circ} \mathrm{E}$ transect discussed by Bauch et al. [47]. A small lens of fresher and warmer waters was observed at station 5595. A similar lens was noted in 2015, but it was larger and located further from the coast. It very likely was formed due to the "offshore" atmospheric forcing [47].

The vertical salinity structure and distribution of freshwater fraction at the transect from the Khatanga River estuary to the continental slope are discussed in detail by Osadchiev et al. [48]. Shortly, the Khatanga plume was weakly-stratified and occupied the whole water column in the shallow inner part of the estuary (stations 5627-2629) due to intense tidal mixing in the Khatanga Gulf. Tidal-induced dilution caused an increase of surface salinity and depth of the plume from 4-7 m (station 5628) to 17-25 m (station 5630) at $120 \mathrm{~km}$ along the transect. In the outer part of the estuary, the plume detached from sea bottom and its depth steadily decreased to $11 \mathrm{~m}$, while surface salinity increased to 21 (station 5632). Penetration of marine waters (with salinity above 30) into the bay was observed up to Bolshoy Begichev Island. Closer to the mouth in the bottom layer, salinity gradually decreased from 25 to 7 (Figure 5). The impact of the Khatanga River fresh waters decreased sharply not far from the entrance to the open sea (station 5633) due to primarily moderate Khatanga River flow, which is about five times smaller than that of the Lena River [49]. The boundary of freshened water lies above the $25 \mathrm{~m}$ isobath. The surface water temperature varied from $3{ }^{\circ} \mathrm{C}$ in the Khatanga River estuary to $-1{ }^{\circ} \mathrm{C}$ near the continental slope (station 5635). Deep waters $(>30 \mathrm{~m}$ ) were characterized by temperatures below zero (Figure 5). 

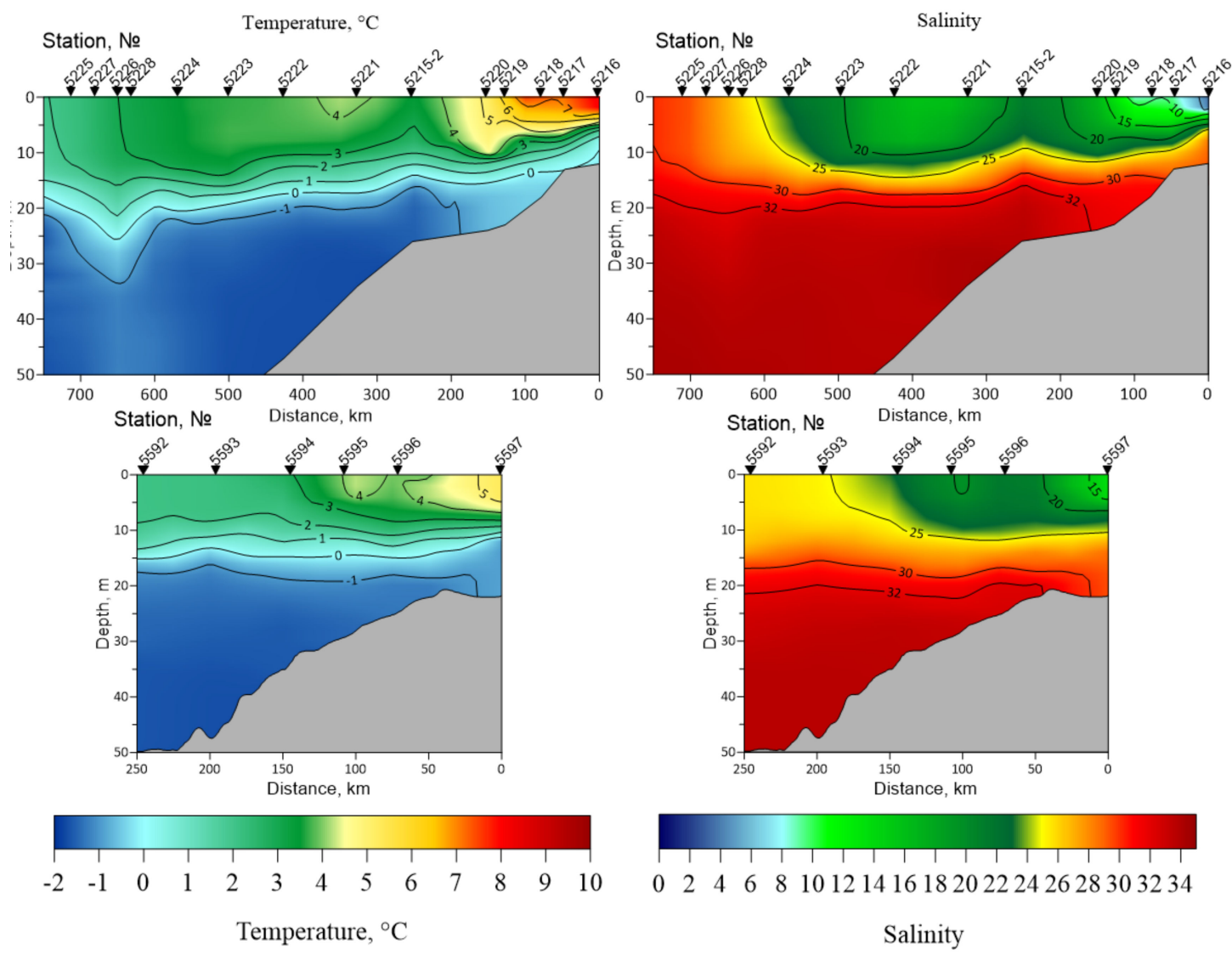

Figure 4. Temperature and salinity across the mixing zones of the Lena River in fall 2015 (upper) and 2017 (lower).
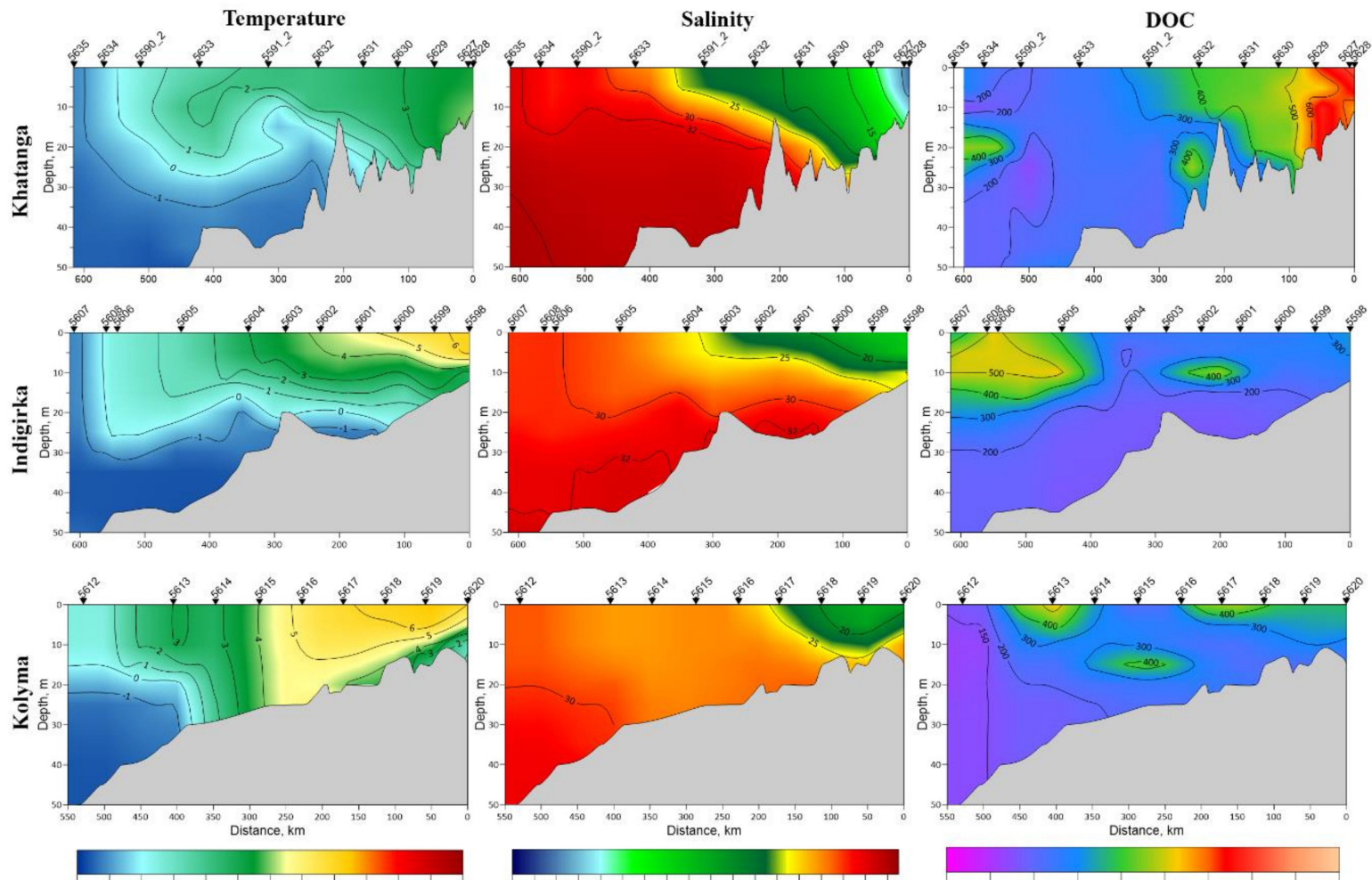

$\begin{array}{lllllllllllll}-2 & -1 & 0 & 1 & 2 & 3 & 4 & 5 & 6 & 7 & 8 & 9 & 10\end{array}$

Temperature, ${ }^{\circ} \mathrm{C}$

Salinity

$\begin{array}{llllllllll}0 & 100 & 200 & 300 & 400 & 500 & 600 & 700 & 800 & 900\end{array}$ DOC, uM

Figure 5. Distribution of temperature, salinity, and DOC along the Khatanga, Indigirka, and Kolyma transects. 


\subsubsection{East Siberian Sea}

In the East Siberian Sea, surface water temperature decreased from south to north (Figure 5). At the section from the Indigirka River to the continental slope, the surface water temperature near the river mouth reached $6.2{ }^{\circ} \mathrm{C}$ and gradually decreased to $-1.4{ }^{\circ} \mathrm{C}$ at station 5607 located near the ice edge. Negative temperatures of bottom water were observed on the inner shelf (station 5601) at the depth of $26 \mathrm{~m}$. Low-salinity waters supplied by the river runoff extend to a depth of 10-15 m. At the transect from Kolyma River estuarine region to the continental slope, the surface water temperature on the inner shelf was $6.7^{\circ} \mathrm{C}$ (stations 5619 and 5620) and decreased to 0.5 at the northern station 5612 . In most of the Kolyma section, the total temperature difference in the water column did not exceed 1 degree. Salinity of surface waters increased from southwest to northeast (Figure 5). In the shelf area adjacent to the estuaries of the Kolyma and Indigirka, the minimum salinity was 17 and 15, respectively. The maximum salinity values were recorded at the northernmost stations 5607 (30 and 32.5 at the surface and bottom, respectively) and 5612 (29.2 and 31.2). The vertical distribution of salinity at the Indigirka section showed a pronounced freshened surface water layer, typical for the Arctic shelf under the influence of continental runoff. A unique feature of the eastern part of the East Siberian Sea (Kolyma transect) was a region of nearly $150 \mathrm{~km}$ of practically homogenous vertically mixed water column. This area may provide vertical convection down to the bottom during autumn water cooling.

\section{3. $D O C$}

The concentration of DOC in seawater of Arctic seas varied in a wide range between 82.8 and $886.7 \mu \mathrm{M}$. The complete DOC dataset is given in Supplementary Table S2. In the Kara and Laptev seas, the higher DOC concentrations were measured for the upper fresher water layer in the mixing zones formed under the influence of $\mathrm{Ob}$, Yenisei, Lena, and Khatanga runoff (Figures 3 and 5, Tables 1 and 2). In the Kara Sea, the mean DOC content in the upper 25-m water layer was approximately two-fold higher compared to deep waters below $25 \mathrm{~m}$. In the Blagopoluchiya Bay, the DOC was lower, compared with the data obtained recently for the Oga and Tsivolki Bays in the case of the western distribution of low-salinity riverine waters [35]. It confirms that terrestrial-derived DOM, supplied by $\mathrm{Ob}$ and Yenisei rivers, represents the main DOM source in the bays of Severny Island of Novaya Zemlya archipelago. At the transect from the Kolyma River mixing zone to the East Siberian Sea continental slope, DOC varied between 125.8 and $505.0 \mu \mathrm{M}$ for the salinity rage 17.0-31.5. The Indigirka transect covered a larger salinity gradient from 15.2 to 33.4. The values of DOC varied there from 165.0 to $526.7 \mu \mathrm{M}$. The surface waters of the transect were characterized by moderate DOC concentrations of 236.7-393.3 $\mu \mathrm{M}$ with its local increase at the station 5606 up to $520.0 \mu \mathrm{M}$. In contrast to the Kara and Laptev seas, the linkage between DOC and hydrological parameters in the East Siberian Sea was not observed. DOC was distributed rather randomly, showing that significant DOC concentrations of 300-526.7 $\mu \mathrm{M}$ were typical for both Indigirka and Kolyma mixing zones and continental slope region. The DOC values measured in 2017 in the East Siberian Sea were higher than the ones reported by Alling et al. [50]. Thus, in 2008, the upper water layer of $15 \mathrm{~m}$ to the west of $160^{\circ} \mathrm{E}$ was characterized by mean DOC of $170 \mu \mathrm{M}$ (mean salinity $S=22)$, and to the east of $160^{\circ} \mathrm{E} 93 \mu \mathrm{M}(\mathrm{S}=28)$. In the present study, corresponding mean DOC concentrations were $285.1 \mu \mathrm{M}(\mathrm{S}=26.0)$ and $168.1 \mu \mathrm{M}(\mathrm{S}=29.7)$. 
Table 1. Variation of DOC and optical characteristics of the Kara Sea waters.

\begin{tabular}{cccc}
\hline & $\mathbf{0 - 2 5} \mathbf{~ m}$ & $\mathbf{> 2 5} \mathbf{~ m}$ & Blagopoluchiya Bay \\
\hline $\mathrm{DOC}(\mu \mathrm{M})$ & $114.2-575.0$ & $110.0-175.8$ & $96.7-145.8$ \\
$a_{\mathrm{CDOM}}(350)\left(\mathrm{m}^{-1}\right)$ & $0.22-5.73$ & $0.27-1.07$ & $0.32-0.75$ \\
$a_{\mathrm{CDOM}}(375)\left(\mathrm{m}^{-1}\right)$ & $0.14-3.64$ & $0.16-0.64$ & $0.19-0.45$ \\
$\mathrm{~S}_{275-295}\left(\mu \mathrm{m}^{-1}\right)$ & $17.78-26.46$ & $22.79-29.32$ & $16.65-18.63$ \\
$\mathrm{~S}_{\mathrm{R}}$ & $0.98-3.08$ & $0.92-1.08$ & $\mathrm{n} / \mathrm{a}$ \\
$\mathrm{SUVA}\left(\mathrm{m}^{2} \mathrm{gC}^{-1}\right)$ & $0.48-2.30$ & $0.39-0.79$ & $0.65-0.76$ \\
\hline
\end{tabular}

Table 2. Variation of DOC and optical characteristics of the Laptev Sea and East Siberian Sea shelf waters (2017).

\begin{tabular}{|c|c|c|}
\hline & 0-10 m & $>10 \mathrm{~m}$ \\
\hline \multicolumn{3}{|c|}{ Lena } \\
\hline $\mathrm{DOC}(\mu \mathrm{M})$ & $242.5-886.7$ & $125.0-337.5$ \\
\hline$a_{\mathrm{CDOM}}(350)\left(\mathrm{m}^{-1}\right)$ & 2.36-11.17 & $0.54-1.72$ \\
\hline$a_{\mathrm{CDOM}}(375)\left(\mathrm{m}^{-1}\right)$ & $1.44-7.20$ & $0.34-1.48$ \\
\hline $\mathrm{S}_{275-295}\left(\mu \mathrm{m}^{-1}\right)$ & $16.38-20.35$ & $19.53-23.35$ \\
\hline$S_{R}$ & $0.91-1.15$ & $1.12-2.08$ \\
\hline $\operatorname{SUVA}\left(\mathrm{m}^{2} \mathrm{~g} \mathrm{C}^{-1}\right)$ & $1.72-2.52$ & $0.38-1.28$ \\
\hline \multicolumn{3}{|c|}{ Khatanga } \\
\hline $\mathrm{DOC}(\mu \mathrm{M})$ & $145.8-727.5$ & $158.3-678.3$ \\
\hline$a_{\mathrm{CDOM}}(350)\left(\mathrm{m}^{-1}\right)$ & $0.57-11.21$ & $0.27-7.02$ \\
\hline$a_{\mathrm{CDOM}}(375)\left(\mathrm{m}^{-1}\right)$ & $0.31-7.21$ & $0.15-4.68$ \\
\hline $\mathrm{S}_{275-295}\left(\mu \mathrm{m}^{-1}\right)$ & $15.81-24.84$ & $14.14-25.24$ \\
\hline$S_{R}$ & $0.92-1.39$ & $0.97-2.39$ \\
\hline SUVA $\left(\mathrm{m}^{2} \mathrm{~g} \mathrm{C}^{-1}\right)$ & $0.59-2.48$ & $0.24-3.35$ \\
\hline \multicolumn{3}{|c|}{ Indigirka } \\
\hline $\mathrm{DOC}(\mu \mathrm{M})$ & $195.8-526.7$ & $165.0-319.17$ \\
\hline$a_{\mathrm{CDOM}}(350)\left(\mathrm{m}^{-1}\right)$ & $0.74-3.77$ & $0.64-2.26$ \\
\hline$a_{\mathrm{CDOM}}(375)\left(\mathrm{m}^{-1}\right)$ & $0.42-2.41$ & $0.38-1.38$ \\
\hline $\mathrm{S}_{275-295}\left(\mu \mathrm{m}^{-1}\right)$ & $18.73-24.45$ & 19.17-23.81 \\
\hline$S_{R}$ & $1.00-1.38$ & $0.92-1.97$ \\
\hline SUVA $\left(\mathrm{m}^{2} \mathrm{~g} \mathrm{C}^{-1}\right)$ & $0.35-2.6$ & $0.1-2.0$ \\
\hline \multicolumn{3}{|c|}{ Kolyma } \\
\hline $\mathrm{DOC}(\mu \mathrm{M})$ & $125.83-505$ & $129.0-425.0$ \\
\hline$a_{\mathrm{CDOM}}(350)\left(\mathrm{m}^{-1}\right)$ & $0.48-3.35$ & $0.47-1.21$ \\
\hline$a_{\mathrm{CDOM}}(375)\left(\mathrm{m}^{-1}\right)$ & $0.43-3.07$ & $0.27-0.73$ \\
\hline$S_{275-295}\left(\mu \mathrm{m}^{-1}\right)$ & $19.36-26.21$ & 21.39-25.84 \\
\hline$S_{R}$ & $0.94-2.07$ & $0.91-2.20$ \\
\hline SUVA $\left(\mathrm{m}^{2} \mathrm{~g} \mathrm{C}^{-1}\right)$ & $0.32-1.71$ & $0.12-1.19$ \\
\hline
\end{tabular}

\subsection{Optical indices}

\subsubsection{Kara Sea}

CDOM concentrations, depicted as $a_{\mathrm{CDOM}}$ (375) [51], followed similar trends to that observed for DOC. The surface of mostly freshened waters had the highest $a_{\mathrm{CDOM}}(375)$ (up to 3.64 and the mean value $1.43 \mathrm{~m}^{-1}$ ), while $a_{\mathrm{CDOM}}(375)$ of Blagopoluchiya Bay and Kara Sea deep waters did not exceed $0.64 \mathrm{~m}^{-1}$ (Table 1 ).

Spectral slope ratio $S_{R}$ varies between 0.9-3.4. It strongly correlates with $a_{\mathrm{CDOM}}(375)$ showing exponential decrease to the values, typical for the $\mathrm{Ob}(\sim 0.87)$ and Yenisei $(\sim 0.91)$ freshwaters reported by Stedmon et al. [26], see also Discussion Section. Similar dependence was obtained for the $S_{275-295}$ spectral slope, indicating the predominance of terrestrial material in a fewer number of samples $\left(S_{275-295}<20\right)$ and mixed or mostly autochthonous DOM character for the others. Interestingly, the data from Blagopoluchiya Bay are grouped separately in the $S_{275-295}-a_{\mathrm{CDOM}}(375)$ plot and differ by the lower $\mathrm{S}_{275-295}$ values (Figure 6). It apparently reflects local input of terrestrial-derived material from Novaya Zemlya island. 


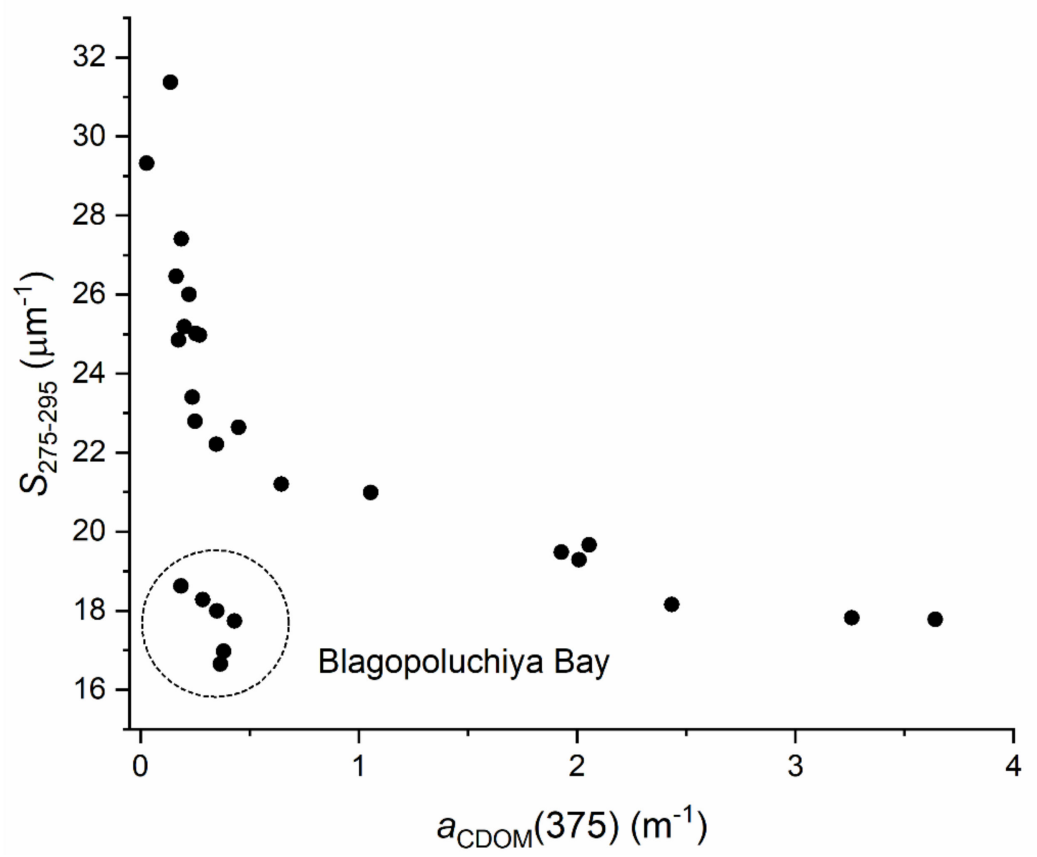

Figure 6. Spectral slope $S_{275-295}$ plotted against $a_{\mathrm{CDOM}}(375)$ for the Kara Sea waters.

SUVA varied between 0.39 and $2.30 \mathrm{~m}^{2} \mathrm{~g} \mathrm{C}^{-1}$ with the highest values observed for the upper water layer. Since SUVA has been shown to be positively correlated to molecular weight [52] and also to be one of the most reliable parameters for the DOM source discrimination with regard to its changes during bio- and photodegradation [53], we suggest the upper water layer DOM to have higher molecular weight, which is explained by a larger fraction of humic acids [54] supplied by $\mathrm{Ob}$ and Yenisei rivers. SUVA values of the Kara Sea waters were found to be lower than the ones of the $\mathrm{Ob}\left(2.58-2.75 \mathrm{~m}^{2} \mathrm{~g} \mathrm{C}^{-1}\right)$ and Yenisei (1.95-2.97 $\left.\mathrm{m}^{2} \mathrm{~g} \mathrm{C}^{-1}\right)$ end members [26].

\subsubsection{Laptev Sea}

CDOM optical properties suggest the dominance of terrigenous humic substances in surface and thermocline waters $\left(\sim 10 \mathrm{~m}\right.$ layer) at the transect along the $130^{\circ} \mathrm{E}$ (see Table 2). Absorption coefficient $a_{\mathrm{CDOM}}(375)$ varied between 0.34 and $7.20 \mathrm{~m}^{-1}$. The lowest absorption coefficient $a_{\mathrm{CDOM}}(350)$ was measured for the bottom waters from the station 5592 and amounted to $0.5 \mathrm{~m}^{-1}$, which is close to the ones reported for the Polar Waters of the East Greenland Current [55,56]. In the study of Pugach et al. [57] a comparable spatial variability of $a_{\mathrm{CDOM}}(350)$ was demonstrated. The maximal $a_{\mathrm{CDOM}}(350)$ of 11.2 measured for the surface waters with salinity 6.6 (station 5596_2) was slightly lower than the one reported for a mid-flow regime of the Lena River of about $13.1 \mathrm{~m}^{-1}$ [58]. The values of $a_{\mathrm{CDOM}}(350)$ were found to be lower compared to the data reported by Gonçalves-Araujo et al. for the Lena Delta region [46] $\left(0.9<a_{\mathrm{CDOM}}(350)<15.7 \mathrm{~m}^{-1}\right)$, which is likely explained by a smaller terrestrial CDOM contribution. Spectral slope $S_{275-295}$ varied between 16.38 $20.35 \mu \mathrm{m}^{-1}$. Spectral slope ratios $S_{R}$ obtained in the present study $\left(0.9<S_{R}<1.2\right)$ are generally consistent with the results of Pugach et al. [57] and Gonçalves-Araujo et al. [46] (2015) ( 0.87-1.00) for the Lena Delta—sea mixing zone. For comparison, $S_{R}$ values of the Lena River water samples were reported to vary between seasons and estimated by Stedmon et al. [26] as 0.81-0.89. Higher $S_{R}$ values were typical for deep waters at depths $15-44 \mathrm{~m}$, see Table 2. Values of SUVA of the upper $10 \mathrm{~m}$ water layer fall in the range $1.72<\mathrm{SUVA}<2.52 \mathrm{~m}^{2} \mathrm{~g} \mathrm{C}^{-1}$, which is comparable with the results $1.33<\mathrm{SUVA}<$ $4.80 \mathrm{~m}^{2} \mathrm{~g} \mathrm{C}^{-1}$ reported by Gonçalves-Araujo et al. [46] for salinities of 0.90-32.63. For deep waters with salinities $30.1-33.9$, SUVA varied from 0.38 to $1.28 \mathrm{~m}^{2} \mathrm{~g} \mathrm{C}^{-1}$, indicating a lower impact of terrestrial-derived DOM. 
The Khatanga discharge experienced intense estuarine tidal mixing and therefore was distributed from surface to the bottom in the inner estuary and over the 20-25 m deep water column in the outer estuary, see Section 3.2.2 and the study of Osadchiev et al. [48]. The difference in DOC concentration and CDOM absorption between the upper and deep waters was, therefore, not as pronounced as for the Kara Sea and the Lena Delta region Tables 1 and 2. The data for salinities above and below 25 are summarized in Supplementary Table S4 for convenience. At the beginning of the transect (stations 5627,5629 and 5630), the entire water column was characterized by maximal along the transect values of absorption $\left(a_{\mathrm{CDOM}}(375)\right.$ was $\left.2.29-7.10 \mathrm{~m}^{-1}\right)$ and specific absorbance SUVA (1.44-2.48 $\left.\mathrm{m}^{2} \mathrm{~g} \mathrm{C}^{-1}\right)$, while $S_{275-295}\left(15.73-16.40 \mu \mathrm{m}^{-1}\right)$ and $S_{R}(0.92-1.09)$ were low. This indicates the predominance of terrigenous CDOM in this location [12,37]. Further north (stations 5631-5633), the contribution of terrigenous CDOM decreases and becomes significant in the upper 10-20 m water layer only (Figure 7). In contrast, deep waters had lower absorption and SUVA $\left(0.32-0.93\right.$, mean $\left.0.75 \mathrm{~m}^{2} \mathrm{~g} \mathrm{C}^{-1}\right)$. The increase of spectral slope $S_{275-295}$ was observed for the bottom waters. At the northernmost stations of the section, the waters of different optical characteristics were observed at depths 10-40 m. They were characterized as being higher compared to oceanic waters [12] absorption at $375 \mathrm{~nm}\left(a_{\mathrm{CDOM}}(375)\right.$ was $\left.3.0 \mathrm{~m}^{-1}\right)$ and $S_{275-295}$ values typical for estuarine and coastal waters with strong humic character $\left(14.1-18.5 \mu \mathrm{m}^{-1}\right)$. At the same time, high salinities and spectral slope ratio $S_{R}$ varying from 2.23-2.39 clearly indicates the presence of oceanic and/or photodegraded terrestrial CDOM. We, therefore, assume that increased absorption at $375 \mathrm{~nm}$ is related to the recently produced CDOM $[59,60]$.
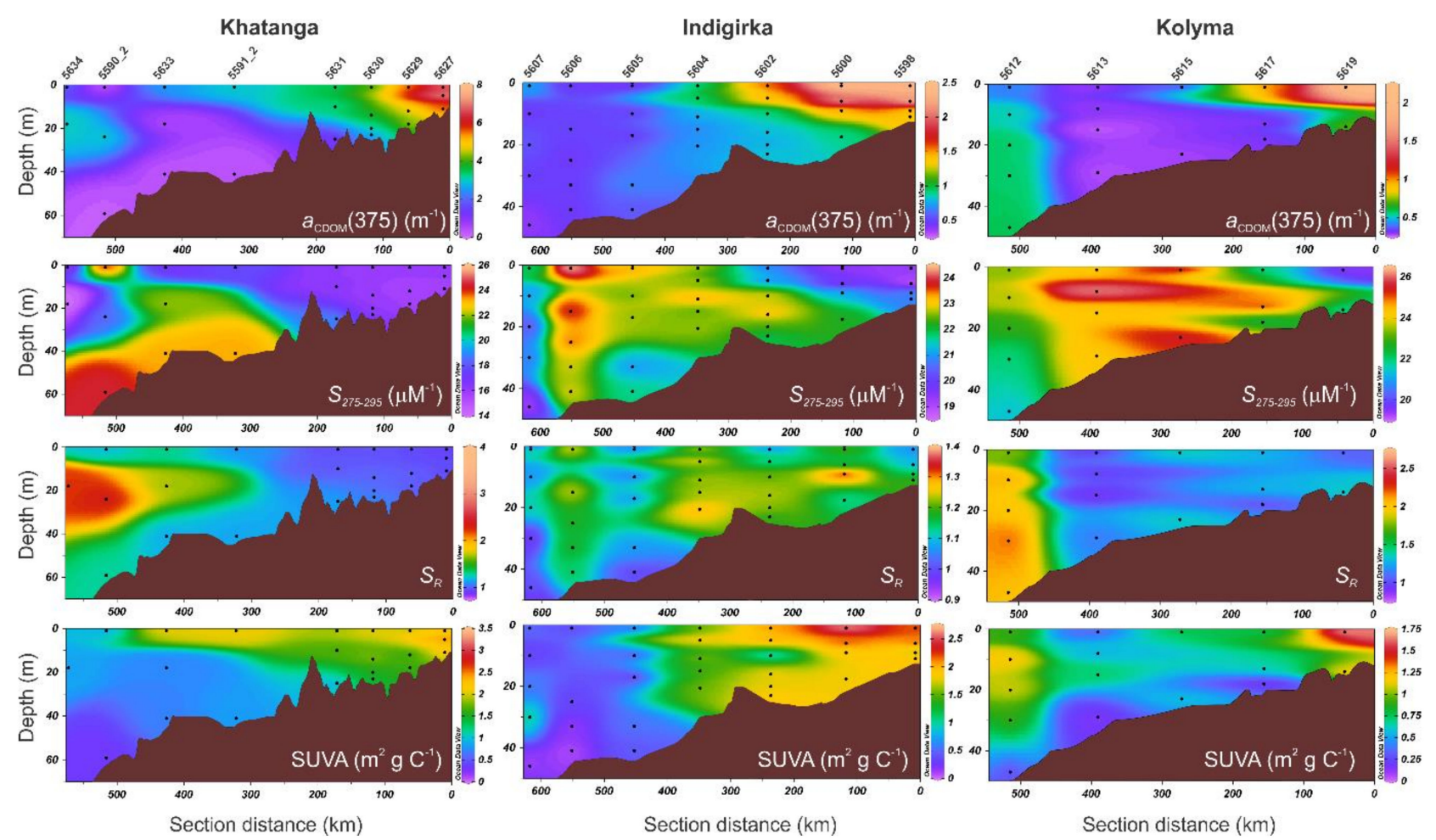

Figure 7. Distribution of $a_{\mathrm{CDOM}}(375), \mathrm{S}_{275-295}, \mathrm{~S}_{\mathrm{R}}$ and SUVA along the Khatanga, Indigirka, and Kolyma transects.

\subsubsection{East Siberian Sea}

At the beginning of the transect from the Indigirka River mixing zone to the continental slope, the values of $a_{\mathrm{CDOM}}(375)$ were typical for estuaries and coastal waters [12] and accounted for $0.7-2.4 \mathrm{~m}^{-1}$. The waters farthest from the coast (stations 5605-5607) exhibited lower $a_{\mathrm{CDOM}}(375)$ values of $0.38-0.56 \mathrm{~m}^{-1}$, which is a characteristic of oceanic waters [59]. Spectral slope $S_{275-295}$ and $S_{R}$ were distributed along the transect rather ir- 
regularly (Figure 7), resulting in similar mean values for the upper $10 \mathrm{~m}$ water layer and deep waters. Spectral slope ratio $S_{R}$ varied between 0.9 and 1.4, indicating that CDOM had a weak humic character and intermediate or strong autochthonous component. The mean values of the specific UV absorbance were $1.45 \mathrm{~m}^{2} \mathrm{~g} \mathrm{C}^{-1}$ for the upper water layer and $1.0 \mathrm{~m}^{2} \mathrm{~g} \mathrm{C}^{-1}$ for the deep waters and testify the predominance of algae and bacterial CDOM. The surface waters of the inner plume (stations 5598-5602) exhibited SUVA up to $2.6 \mathrm{~m}^{2} \mathrm{~g} \mathrm{C}^{-1}$ caused by the presence of terrestrial-derived DOM supplied by the Indigirka River.

Pronounced plume was not seen from the Kolyma River. The impact of the Kolyma River waters was notable for over $150 \mathrm{~km}$ from the beginning of the transect (stations 2619 and 5617). Absorption at $375 \mathrm{~nm}$ was about 1.5 times lower compared to the Indigirka transect. The maximal $a_{\mathrm{CDOM}}(375)$ values were measured for the inner plume $\left(1-2.1 \mathrm{~m}^{-1}\right)$, as well as for the entire water column at the northernmost station 5612. Similar to the Khatanga transect, an increase in absorption at $375 \mathrm{~nm}$, observed at salinities $>29$, was accompanied by a decrease in $S_{275-295}$ and by an increase in $S_{R}$, which indicates the recently produced CDOM. The values of $a_{\mathrm{CDOM}}(350)$ and $S_{R}$ obtained in the present study are consistent with the data reported by Pugach et al. [57]. The values of SUVA were below $1.8 \mathrm{~m}^{2} \mathrm{~g} \mathrm{C}^{-1}$ for all the samples, showing little freshwater input.

\section{Discussion}

\subsection{Conservative DOC Behavior in the Kara and Laptev Seas}

The DOC versus salinity plot (Figure 8 ) for the Kara Sea showed that the data fell close to the DOC $=927.3-23.0 \times$ Salinity regression line, characterized by the coefficient of determination $R^{2}=0.91$. No difference in conservative DOM distribution was found between surface (open circles) and depth profile (filled circles) samples. This agreed well with the observations reported by Stein et al. [7], suggesting similar vertical and horizontal mixing in the $\mathrm{Ob}$ and Yenisei estuaries. The conservative DOM behavior in the Kara Sea was demonstrated recently by several studies [19,35,61-63]. We summarized the coefficients $a$ and $b$ for the regression line DOC $=a-b \times$ Salinity, obtained during late summer and fall periods 1997-2017 in Supplementary Table S3.

In September 2015, the DOC at the transect along $130^{\circ} \mathrm{E}$ (Laptev Sea) was distributed conservatively. A negative correlation of DOC with respect to salinity is described by the following equation: DOC $=545.5-10.4 \times$ Salinity, $R^{2}=0.74$. In September 2017, four stations were examined for DOC (stations 5592 and 5596 on the way there and back, 5592_2 and 5596_2). Higher DOC values were observed and accounted to $887 \mu \mathrm{M}$ at salinity 6.6. Assuming conservative DOM behavior, our estimates for the DOC in fresh water are $545.5 \mu \mathrm{M} \mathrm{C}$ and 1015.4 $\mu \mathrm{M} \mathrm{C}$ in 2015 and 2017, respectively. These results are in a good agreement with the data reported previously (506-1252 $\mu$ M C) $[26,46,64-68]$. The mean DOC concentrations for the upper and deep waters are consistent with the data given by Alling et al. [50].

At the transect from the Khatanga River to continental slope, a linear correlation DOC - salinity was described as DOC $=802.6-19.3 \times$ Salinity, $R^{2}=0.97$, for salinities varying from 3.5-31.5 (Figure 8). Considering conservative DOC behavior within the Khatanga River mixing zone, our evaluation of DOC in the Khatanga River is $802 \mu \mathrm{M}$. It is almost twofold higher compared to the DOC value of $472 \mu \mathrm{M}$ reported by Wheeler at al. [33]. This assessment was based on the mean TOC in the Khatanga River and typical for Russian rivers mean fraction of $\mathrm{DOC} / \mathrm{TOC}=0.9$ [34]. According to the data on annual variation of DOC in six major Arctic rivers [26], DOC concentration in September can exceed the mean annual value no more than $10 \%$ (Ob and Kolyma rivers). For the Mackenzie, Yenisei, Yukon, and Lena rivers, the mean annual DOC was found to be even higher than DOC measured during the period from the end of August to the beginning of October. We, therefore, assume that the mean annual DOC concentration of $472 \mu \mathrm{M}$ in the Khatanga River waters might be underestimated. 

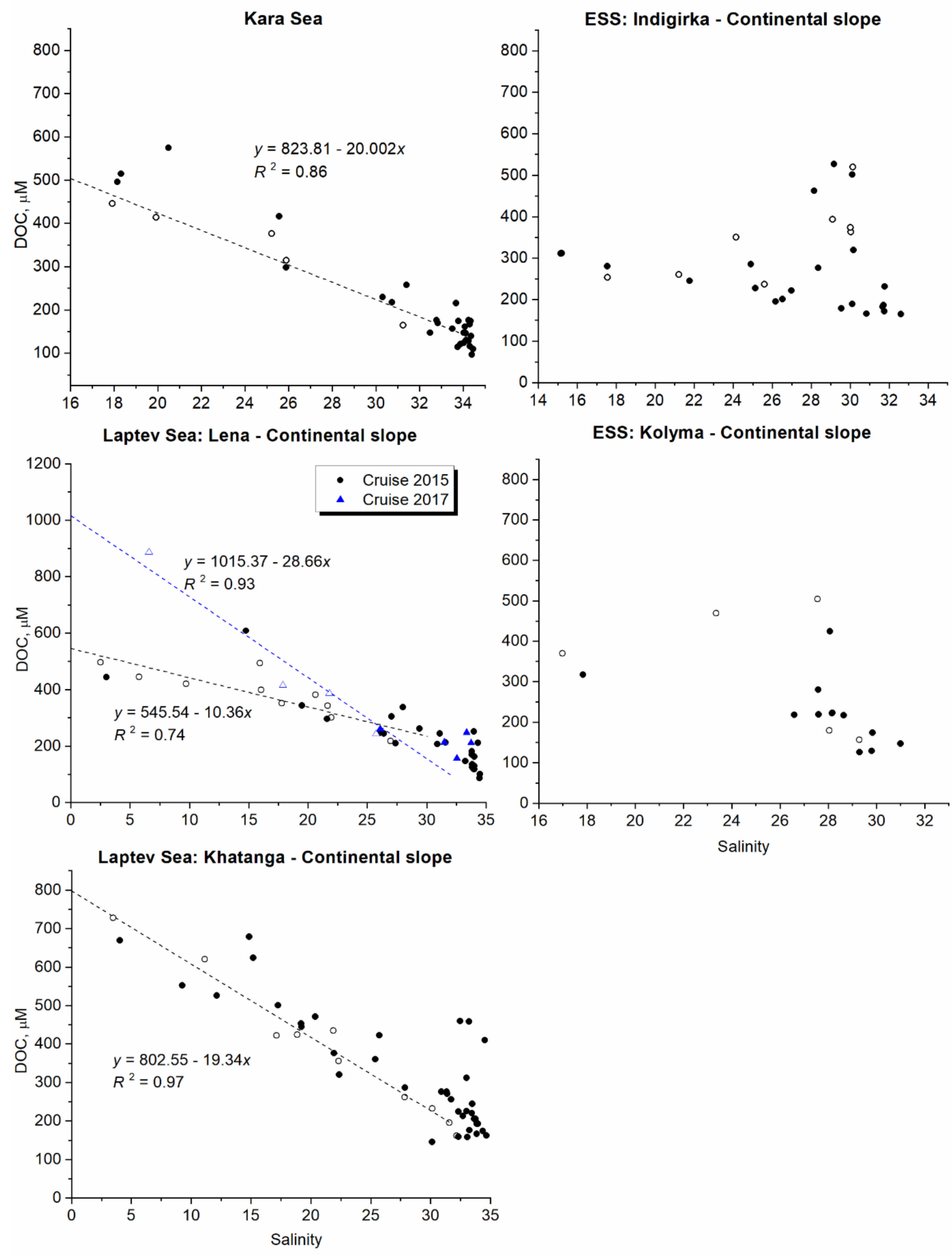

Figure 8. Distribution of DOC along the salinity gradient in the Kara, Laptev, and East Siberian seas. The data on surface and subsurface (1 $\mathrm{m}$ depth) waters are shown by open circles.

\subsection{Nonconservative DOC Behavior in the East Siberian Sea}

In the study of Alling et al. [50], nonconservative DOM behavior was revealed in the East Siberian Sea. It was related to the DOM removal, which explained the net DOC deficit. The field studies conducted in 2017 have also demonstrated nonconservative DOC distribution along the salinity gradient in the East Siberian Sea (Figure 8). While in the 
Arctic region, the maximum DOC content is usually a characteristic of low-salinity waters of the mixing zones affected by river runoff, in this study the regions of the Arctic shelf remote from the estuaries and deltas showed DOC concentrations that were comparable with the ones observed at lower salinities. In order to identify the samples with a high DOC content, which was not caused by newly released terrestrial-derived material, we plotted DOC against absorption coefficient at $350 \mathrm{~nm}$ (Figure 9A). The substantial DOC concentrations of $>300 \mu \mathrm{M}$ and $a_{\mathrm{CDOM}}(350)<2 \mathrm{~m}^{-1}$ were found at the farthest from the coast stations of the Indigirka section (5605-5607) as well as in the upper $15 \mathrm{~m}$ water layer throughout the entire Kolyma section (stations 5613, 5615 and 5617). The possible mechanisms of formation of high salinity waters exhibiting high DOC concentration is an autochthonous DOM production, which is one of the major DOM sources to the marine environment with limited continental influence [69,70]. This assumption is supported by the increase in the above areas the spectral slope $S_{275-295}$ (Figure 7). A similar increase in the DOC content, accompanied by an increase in absorption in the short-wavelength spectral range, was observed in the region of the continental slope in the Khatanga section (station 5634).
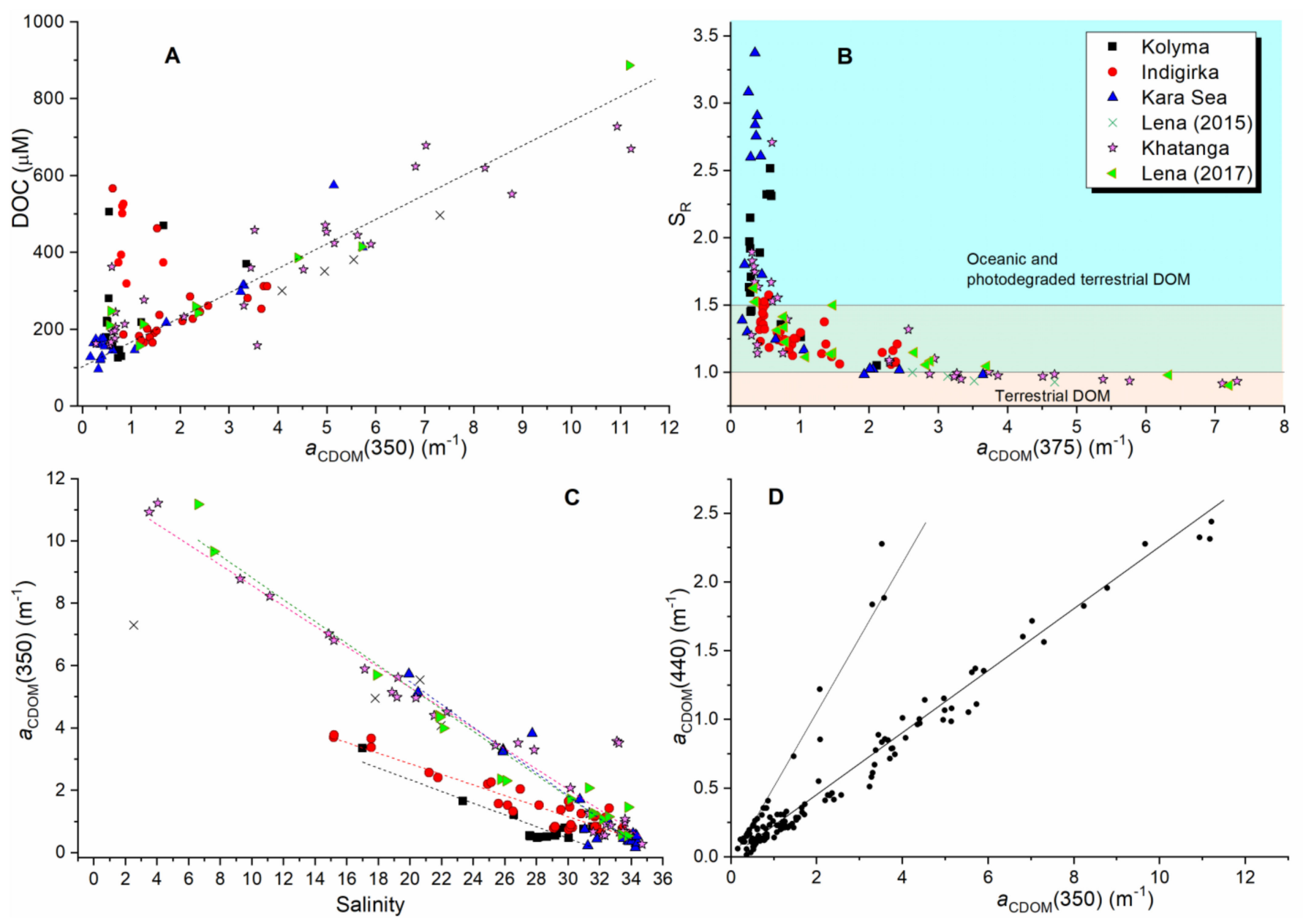

Figure 9. (A)—DOC against absorption coefficient at $350 \mathrm{~nm}$ for the studied samples; (B) —spectral slope ratio plotted against the absorption coefficient at $375 \mathrm{~nm} ;(\mathbf{C})-a_{\mathrm{CDOM}}(350)$ against salinity for the individual mixing zones; (D) $-a_{\mathrm{CDOM}}(440)$ plotted against $a_{\mathrm{CDOM}}(350)$.

\subsection{CDOM Sources}

A criterion suggested by Helms et al. [37] for identifying the sources of CDOM shows that the dominant contribution of terrigenous $\mathrm{OM}\left(S_{R}<1\right)$ is a characteristic of the mixing 
zones of the Khatanga and Lena rivers (salinities 3.5-21.5) (Figure 9B). $S_{R}$ values varied between 0.91 and 1. For comparison, $S_{R}$ values for river water samples were reported to vary between seasons and estimated by Stedmon et al. [26] as 0.82-0.92 (Kolyma), 0.81-0.89 (Lena), 0.83-0.92 (Ob), and 0.79-0.93 (Yenisei). CDOM of the Indigirka transect was of mixed autochthonous-allochthonous character, while the stations east of $160^{\circ} \mathrm{E}$ (Kolyma section) are distinguished by the presence of autochthonous CDOM in seawater. This is consistent with the results, published by Semiletov et al. [71], demonstrating that a significant component of freshwater from Siberian river inflows into the coastal East Siberian Sea, extending to approximately $160^{\circ} \mathrm{E}$, where the long-term average position of the Pacific frontal zone is located.

The predominance of autochthonous CDOM was also demonstrated in the area of the Novaya Zemlya Trough, in the Blagopoluchiya Bay, and the northern part of the Khatanga transect. Expectedly, the decrease of the influence of the Lena, Khatanga, Indigirka, and Kolyma river runoff farther seaward along the studied transects was accompanied by an increase of salinity, $S_{275-295}$ and $S_{R}$, while the water temperature, CDOM absorption at 350 and $375 \mathrm{~nm}$, and SUVA decreased. At the northern stations of the Khatanga and Kolyma sections, however, an increase of $a_{\mathrm{CDOM}}(375)$ was observed and very likely was associated with the recently produced DOM [59].

\subsection{CDOM Absorption at $350 \mathrm{~nm}$ and $440 \mathrm{~nm}$}

The absorption coefficient $a_{\mathrm{CDOM}}(350)$ was repeatedly used earlier as a quantitative measure for CDOM concentrations, see for example [58], due to its ability to estimate lignin concentrations and inputs of terrestrial DOM to the Arctic Ocean [26,72]. While no correlation between DOC and salinity was found in the case of mixing zones of the Kolyma and Indigirka rivers, $a_{\mathrm{CDOM}}(350)$ plotted against salinity (Figure $9 \mathrm{C}$ ) showed good correlations described separately for each studied water area in Table 3. We suggest that Indigirka and Kolyma river waters were characterized by similar $a_{\mathrm{CDOM}}(350)$ values of $\sim 6.2 \mathrm{~m}^{-1}$. This is about twofold smaller compared to the Khatanga, Lena, and Ob/Yenisei rivers $\left(\sim 12.3 \mathrm{~m}^{-1}\right)$. The obtained results are consistent with data on the $\mathrm{Ob}$, Lena, and Kolyma rivers during mid-flow [58]. Lower $a_{\mathrm{CDOM}}(350)$ values in the Kolyma River were explained by lower vascular plant inputs during freshet and its more extensive microbial degradation in the Kolyma watershed.

Table 3. Coefficients $a$ and $b$ of the $a_{\mathrm{CDOM}}(350)=a+b \times$ Salinity regression line and corresponding coefficients of determination obtained for the Kara, Laptev, and East Siberian seas during AugustSeptember 2017.

\begin{tabular}{cccc}
\hline & $\boldsymbol{A}$ & $\boldsymbol{B}$ & $\mathbf{R}^{\mathbf{2}}$ \\
\hline Kara Sea & $12.9 \pm 0.6$ & $-0.365 \pm 0.019$ & 0.93 \\
Lena & $12.3 \pm 0.5$ & $-0.352 \pm 0.017$ & 0.96 \\
Khatanga & $11.8 \pm 0.4$ & $-0.327 \pm 0.013$ & 0.94 \\
Indigirka & $6.2 \pm 0.3$ & $-0.170 \pm 0.011$ & 0.87 \\
Kolyma & $6.1 \pm 0.7$ & $-0.188 \pm 0.026$ & 0.77 \\
\hline
\end{tabular}

Another important optical characteristic of seawater is a CDOM absorption coefficient at $440 \mathrm{~nm} a_{\mathrm{CDOM}}(440)$. CDOM represents an essential constituent affecting ocean color. Thus, in the Arctic Ocean, the contribution of $a_{\mathrm{CDOM}}(443)$ to the total non-water absorption can reach $\sim 50 \%$ [73]. It was shown that systematic differences in chlorophyll retrievals resulting from different ocean color models are related to each model's ability to account for the absorption of light by CDOM [14]. In the present study, most of the $a_{\mathrm{CDOM}}(440)$ data showed a good negative correlation with salinity, similar to the ones reported for the $a_{\mathrm{CDOM}}(350)$ absorption coefficients (Figure 9C). Some of the water samples, however, were failed to be described by the linear dependence on salinity due to high absorption coefficients $a_{\mathrm{CDOM}}(440)$; they were taken in the Blagopoluchiya Bay, at the station 5586 in the Kara Sea and northern parts of the Khatanga (stations 5633 surface waters, 5590_2 
$24 \mathrm{~m}$, and 5634 surface waters and $18 \mathrm{~m}$ ) and Kolyma (5612) transects. In the $a_{\mathrm{CDOM}}(350)$ against $a_{\mathrm{CDOM}}(440)$ plot (Figure 9D), such data points are grouped separately, they are characterized by $a_{\mathrm{CDOM}}(350)$ below $4 \mathrm{~m}^{-1}$ and higher $a_{\mathrm{CDOM}}(440)$ values. This group of points that are aligned on a regression line characterized by different slopes represents a group of CDOM absorption spectra characterized by a shallower slope coefficient. The increase of $a_{\mathrm{CDOM}}(440)$ may be caused by autochthonous CDOM. Thus, in the study of the South Brazilian Bight, a strong correlation between Chl-a and $a_{\mathrm{CDOM}}(440)$ was revealed and described with a regression line lying close to the one observed for the global pelagic oceans reported by Bricaud et al. [74]. The CDOM-Chl-a correlation allowed suggesting the presence of an autochthonous source of CDOM to the region driven mostly by the phytoplankton community over the shelf domain [75]. Our assumption is also supported by the study of phytoplankton of the Khatanga transect [76]. It was found that the area of the continental slope in the western Laptev Sea represents a specific local biotope. Phytoplankton in the area of the continental slope was characterized by high abundance and biomass, dominance of diatoms, and the formation of the deep maximum formed by actively growing algae. At the station 5633 , maximum of phytoplankton biomass was observed in surface waters, while at station 5635 (about $40 \mathrm{~km}$ north from 5634), it was found at $45 \mathrm{~m}$ depth.

Obtained results on CDOM absorption can be valuable in remote sensing and modeling issues. For example, calculated from satellite data, CDOM absorption coefficients may be used as an effective indicator of the Kara Sea surface desalinated layer distribution and dynamics [31]. As the values of light absorption in this layer are significantly higher than in surrounding seawaters [56,77], its characteristics must be taken into account in heat budget models.

\section{Conclusions}

The complex field studies, conducted in fall 2015 and 2017, covered a large area of the eastern Arctic shelf of the Kara, Laptev and East Siberian seas. Analysis of DOC concentration and CDOM optical properties, supported by CTD data, allowed us to consider $\mathrm{DOM}$ distribution and its quality in the mixing zones of the Ob/Yenisei, Khatanga, Lena, Indigirka, and Kolyma rivers. It was demonstrated that the Kara and Laptev mixing zones were characterized by conservative DOC and $a_{\mathrm{CDOM}}(350)$ behavior, while the East Siberian sea waters showed nonconservative DOC distribution. We provide the first estimates on DOC content, based on the high-temperature combustion technique, in the Khatanga River during mid-flow regime, it accounted for $802.6 \mu \mathrm{M}(9.6 \mathrm{mg} / \mathrm{L})$. Assuming conservative DOM behavior, our estimates for the DOC in fresh water are $545.5 \mu \mathrm{MC}$ and $1015.4 \mu \mathrm{M}$ C in 2015 and 2017, respectively, which is consistent with the results of previous studies. Despite the individual watershed characteristics of the rivers flowing into the eastern Arctic shelf seas, variation of the absorption at $350 \mathrm{~nm}$ along the salinity gradient was found to be similar for the Laptev and Kara seas. Absorption of the East Siberian Sea waters was found to be two-fold smaller, which is explained by lower CDOM content in the Indigirka and Kolyma rivers, as well as degradation of humic substances supplied by the Lena River during the transport to the East Siberian Sea through the Dmitry Laptev Strait.

Estuarine and delta regions were characterized by the predominance of terrestrialderived DOM supplied by river runoff. The increase of DOC content was observed at the most distant from the shore stations in the area of the continental slope. It was frequently accompanied by growth of absorption at short-wave spectral range $\left(S_{275-295}\right), S_{R}$, and $a_{\mathrm{CDOM}}(440)$, which indicates the production of autochthonous DOM by marine biota to be the dominant CDOM source at those locations. The literature overview also demonstrated the correlation between high DOC values and the increase of phyto- or zooplankton populations.

The OLCI ocean color scanners launched in February 2016 (Sentinel-3A) and in April 2018 (Sentinel-3B) should provide satellite data in the next decade. It was shown by Glukhovets et al. [31] that the standard OLCI algorithm for estimating the CDOM absorp- 
tion coefficient ADG443_NN gives high errors in the Arctic seas. The dataset presented in this work may be used to improve existing standard and regional [78] algorithms and to create new ones.

Supplementary Materials: The following are available online at https:/ / www.mdpi.com/2072-429 2/13/6/1145/s1, Table S1: Sampling dates during the 63rd and 69th cruises of R/V Akademik Mstislav Keldysh, Table S2: Salinity and DOC concentration of water samples, Table S3: Coefficients $a$ and $b$ of the DOC $=a+b \times$ Salinity regression line and corresponding coefficients of determination obtained for the Kara Sea waters during August-September periods 1997-2017, Table S4: DOC and optical characteristics of the Khatanga transect waters (Laptev Sea).

Author Contributions: Conceptualization, A.N.D.; data curation, A.N.D., A.A.N., N.V.L. and S.A.S.; formal analysis, A.N.D.; funding acquisition, A.N.D.; investigation, A.N.D., A.A.N., N.V.L., S.V.P. and S.A.S.; supervision, A.N.D.; visualization, A.A.N. and A.N.D.; writing—original draft preparation, A.N.D. and A.A.N.; writing-review and editing, A.N.D. All authors have read and agreed to the published version of the manuscript.

Funding: The study of the Kara Sea waters was performed in the framework of the state assignment of IO RAS (theme 0128-2021-0016). The study of DOC along the Khatanga and Lena Delta transects was supported by the RFBR (project 18-05-60214). Investigation of CDOM of the East Siberian Sea was supported by the RSF Grant (project 18-77-00053).

Institutional Review Board Statement: Not applicable.

Informed Consent Statement: Not applicable.

Data Availability Statement: The data on DOC and salinity of are given in Supplementary Materials to this study. Spectroscopic indices and CDOM absorbance spectra are provided in [32].

Acknowledgments: The data are included as supporting information. The authors are grateful to Mikhail V. Flint for the opportunity to take part in the impressive complex expeditions to the Arctic shelf seas and the crew of the R/V Akademik Mstislav Keldysh for their contribution during field studies. We thank Dmitry I. Glukhovets, Alexander A. Osadchiev and Marina D. Kravchishina for fruitful discussion, as well as anonymous reviewers for their comments on an earlier version of this paper.

Conflicts of Interest: The authors declare no conflict of interest.

\section{References}

1. Hansell, D.A.; Carlson, C.A.; Repeta, D.J.; Schlitzer, R. Dissolved organic matter in the ocean: A controversy stimulates new insights. Oceanography 2009, 22, 202-211. [CrossRef]

2. Wagner, S.; Schubotz, F.; Kaiser, K.; Hallmann, C.; Waska, H.; Rossel, P.E.; Galy, V. Soothsaying DOM: A current perspective on the future of oceanic dissolved organic carbon. Front. Mar. Sci. 2020, 7, 341. [CrossRef]

3. Romankevich, E.A.; Vetrov, A.A.; Peresypkin, V.I. Organic matter of the World Ocean. Russ. Geol. Geophys. 2009, 50, $299-307$. [CrossRef]

4. Stein, R.; Stein, R.; MacDonald, R.W. The Organic Carbon Cycle in the Arctic Ocean; Springer: Berlin, Germany, 2004.

5. Opsahl, S.; Benner, R.; Amon, R.M.W. Major flux of terrigenous dissolved organic matter through the Arctic Ocean. Limnol. Oceanogr. 1999, 44, 2017-2023. [CrossRef]

6. McClelland, J.W.; Holmes, R.M.; Dunton, K.H.; Macdonald, R.W. The Arctic Ocean Estuary. Chesap. Sci. 2012, 35, 353-368. [CrossRef]

7. Stein, R.; Fahl, K.; Fütterer, D.; Galimov, E.M.; Stepanets, O.V. Siberian River Run-off in the Kara Sea: Characterisation, Quantification, Variability, and Environmental Significance; Elsevier: Amsterdam, The Netherlands, 2003.

8. Yentsch, C.S. The influence of phytoplankton pigments on the colour of sea water. Deep. Sea Res. (1953) 1960, 7, 1-9. [CrossRef]

9. Coble, P.G. Characterization of marine and terrestrial DOM in seawater using excitation-emission matrix spectroscopy. Mar. Chem. 1996, 51, 325-346. [CrossRef]

10. Arrigo, K.; Brown, C. Impact of chromophoric dissolved organic matter on UV inhibition of primary productivity in the sea. Mar. Ecol. Prog. Ser. 1996, 140, 207-216. [CrossRef]

11. Siegel, D.A.; Maritorena, S.; Nelson, N.B.; Hansell, D.A.; Lorenzi-Kayser, M. Global distribution and dynamics of colored dissolved and detrital organic materials. J. Geophys. Res. Space Phys. 2002, 107, 21-1-21-14. [CrossRef]

12. Stedmon, C.A.; Nelson, N.B. The Optical Properties of DOM in the Ocean. In Biogeochemistry of Marine Dissolved Organic Matter; Elsevier BV: Amsterdam, The Netherlands, 2015; pp. 481-508. 
13. Kowalczuk, P.; Olszewski, J.; Darecki, M.; Kaczmarek, S. Empirical relationships between coloured dissolved organic matter (CDOM) absorption and apparent optical properties in Baltic Sea waters. Int. J. Remote. Sens. 2005, 26, 345-370. [CrossRef]

14. Siegel, D.A.; Maritorena, S.; Nelson, N.B.; Behrenfeld, M.J.; McClain, C.R. Colored dissolved organic matter and its influence on the satellite-based characterization of the ocean biosphere. Geophys. Res. Lett. 2005, 32. [CrossRef]

15. D'Ortenzio, F.; Marullo, S.; Ragni, M.; d'Alcalà, M.R.; Santoleri, R. Validation of empirical SeaWiFS algorithms for chlorophyll-a retrieval in the Mediterranean Sea: A case study for oligotrophic seas. Remote Sens. Environ. 2002, 82, 79-94. [CrossRef]

16. Palmer, S.C.; Pelevin, V.V.; Goncharenko, I.; Kovács, A.W.; Zlinszky, A.; Présing, M.; Tóth, V.R. Ultraviolet fluorescence LiDAR (UFL) as a measurement tool for water quality parameters in turbid lake conditions. Remote Sens. 2013, 5, 4405-4422. [CrossRef]

17. Bailly, J.-S.; Montes-Hugo, M.; Pastol, Y.; Baghdadi, N. LiDAR Measurements and Applications in Coastal and Continental Waters. In Land Surface Remote Sensing in Urban and Coastal Areas; Elsevier BV: Amsterdam, The Netherlands, 2016; pp. 185-229.

18. Romankevich, E.A.; Vetrov, A.A. Carbon Cycle in the Arctic Seas of Russia; Nauka Publishers: Moscow, Russia, 2001.

19. Amon, R.M.W. The Role of Dissolved Organic Matter for the Organic Carbon Cycle in the Arctic Ocean. In The Organic Carbon Cycle in the Arctic Ocean; Springer International Publishing: New York, NY, USA, 2004; pp. 83-99.

20. Hansell Dennis, A.; Craig, A. Carlson. Biogeochemistry of Marine Dissolved Organic Matter; Academic Press: Cambridge, MA, USA, 2014.

21. Mann, P.J.; Spencer, R.G.M.; Hernes, P.J.; Esix, J.; Aiken, G.R.; Tank, S.E.; McClelland, J.W.; Butler, K.D.; Dyda, R.Y.; Holmes, R.M. Pan-Arctic Trends in Terrestrial Dissolved Organic Matter from Optical Measurements. Front. Earth Sci. 2016, 4, 25. [CrossRef]

22. Dai, M.; Yin, Z.; Meng, F.; Liu, Q.; Cai, W.-J. Spatial distribution of riverine DOC inputs to the ocean: An updated global synthesis. Curr. Opin. Environ. Sustain. 2012, 4, 170-178. [CrossRef]

23. Nihoul, J. Influence of Climate Change on the Changing Arctic and Sub-Arctic Conditions; Springer: Berlin/Heidelberg, Germany, 2009.

24. McGuire, A.D.; Anderson, L.G.; Christensen, T.R.; Dallimore, S.; Guo, L.; Hayes, D.J.; Heimann, M.; Lorenson, T.D.; Macdonald, R.W.; Roulet, N. Sensitivity of the carbon cycle in the Arctic to climate change. Ecol. Monogr. 2009, 79, 523-555. [CrossRef]

25. Meier, W.N.; Hovelsrud, G.K.; Van Oort, B.E.; Key, J.R.; Kovacs, K.M.; Michel, C.; Haas, C.; Granskog, M.A.; Gerland, S.; Perovich, D.K.; et al. Arctic sea ice in transformation: A review of recent observed changes and impacts on biology and human activity. Rev. Geophys. 2014, 52, 185-217. [CrossRef]

26. Stedmon, C.; Amon, R.; Rinehart, A.; Walker, S. The supply and characteristics of colored dissolved organic matter (CDOM) in the Arctic Ocean: Pan Arctic trends and differences. Mar. Chem. 2011, 124, 108-118. [CrossRef]

27. Jaffé, R.; McKnight, D.; Maie, N.; Cory, R.; McDowell, W.H.; Campbell, J.L. Spatial and temporal variations in DOM composition in ecosystems: The importance of long-term monitoring of optical properties. J. Geophys. Res. Space Phys. 2008, 113. [CrossRef]

28. Harrison, J.A.; Caraco, N.; Seitzinger, S.P. Global patterns and sources of dissolved organic matter export to the coastal zone: Results from a spatially explicit, global model. Glob. Biogeochem. Cycles 2005, 19, GB4S04. [CrossRef]

29. Griffin, C.; McClelland, J.; Frey, K.; Fiske, G.; Holmes, R. Quantifying CDOM and DOC in major Arctic rivers during ice-free conditions using Landsat TM and ETM+ data. Remote. Sens. Environ. 2018, 209, 395-409. [CrossRef]

30. Gonçalves-Araujo, R.; Rabe, B.; Peeken, I.; Bracher, A. High colored dissolved organic matter (CDOM) absorption in surface waters of the central-eastern Arctic Ocean: Implications for biogeochemistry and ocean color algorithms. PLOS ONE 2018, 13, e0190838. [CrossRef]

31. Glukhovets, D.; Kopelevich, O.; Yushmanova, A.; Vazyulya, S.; Sheberstov, S.; Karalli, P.; Sahling, I. Evaluation of the CDOM Absorption Coefficient in the Arctic Seas Based on Sentinel-3 OLCI Data. Remote. Sens. 2020, 12, 3210. [CrossRef]

32. Drozdova, A.N.; Puiman, M.S.; Krylov, I.N.; Patsaeva, S.V.; Shatravin, A.V. Dataset on optical characteristics and spectroscopic indices of dissolved organic matter of the Kara, Laptev, and East Siberian seas in August-September. Data Brief 2019, $26,104562$. [CrossRef]

33. Wheeler, P.; Watkins, J.; Hansing, R. Nutrients, organic carbon and organic nitrogen in the upper water column of the Arctic Ocean: Implications for the sources of dissolved organic carbon. Deep. Sea Res. Part II Top. Stud. Oceanogr. 1997, 44, 1571-1592. [CrossRef]

34. Gordeev, V.V.; Martin, J.M.; Sidorov, I.S.; Sidorova, M.V. A reassessment of the Eurasian river input of water, sediment, major elements, and nutrients to the Arctic Ocean. Am. J. Sci. 1996, 296, 664-691. [CrossRef]

35. Drozdova, A.N.; Patsaeva, S.V.; Khundzhua, D.A. Fluorescence of dissolved organic matter as a marker for distribution of desalinated waters in the Kara Sea and bays of Novaya Zemlya archipelago. Oceanology 2017, 57, 41-47. [CrossRef]

36. Amante, C.; Eakins, B.W. ETOPO1 1 arc-minute global relief model: Procedures, data sources and analysis. NOAA Technical Memorandum NESDIS NGDC-24. Natl. Geophys. Data Cent. 2009, 10, V5C8276M.

37. Helms, J.R.; Stubbins, A.; Ritchie, J.D.; Minor, E.C.; Kieber, D.J.; Mopper, K. Absorption spectral slopes and slope ratios as indicators of molecular weight, source, and photobleaching of chromophoric dissolved organic matter. Limnol. Oceanogr. 2008, 53, 955-969. [CrossRef]

38. Bricaud, A.; Morel, A.; Prieur, L. Absorption by dissolved organic matter of the sea (yellow substance) in the UV and visible domains1. Limnol. Oceanogr. 1981, 26, 43-53. [CrossRef]

39. Derrien, M.; Yang, L.; Hur, J. Lipid biomarkers and spectroscopic indices for identifying organic matter sources in aquatic environments: A review. Water Res. 2017, 112, 58-71. [CrossRef] 
40. Weishaar, J.L.; Aiken, G.R.; Bergamaschi, B.A.; Fram, M.S.; Fujii, R.; Mopper, K. Evaluation of Specific Ultraviolet Absorbance as an Indicator of the Chemical Composition and Reactivity of Dissolved Organic Carbon. Environ. Sci. Technol. 2003, 37, 4702-4708. [CrossRef] [PubMed]

41. Drozdova, A.N.; Kravchishina, M.D.; Khundzhua, D.A.; Freidkin, M.P.; Patsaeva, S.V. Fluorescence quantum yield of CDOM in coastal zones of the Arctic seas. Int. J. Remote Sens. 2018, 39, 9356-9379. [CrossRef]

42. Pavlov, V.K.; Pfirman, S.L. Hydrographic structure and variability of the Kara Sea: Implications for pollutant distribution. Deep Sea Res. Part Ii Top. Stud. Oceanogr. 1995, 42, 1369-1390. [CrossRef]

43. Glukhovets, D.I.; Goldin, Y.A. Surface layer desalination of the bays on the east coast of Novaya Zemlya identified by shipboard and satellite data. Oceanology 2019, 61, 68-77. [CrossRef]

44. Zatsepin, A.G.; Zavialov, P.O.; Kremenetskiy, V.V.; Poyarkov, S.G.; Soloviev, D.M. The upper desalinated layer in the Kara Sea. Oceanology 2010, 50, 657-667. [CrossRef]

45. Olsson, K.; Anderson, L.G. Input and biogeochemical transformation of dissolved carbon in the Siberian shelf seas. Cont. Shelf Res. 1997, 17, 819-833. [CrossRef]

46. Gonçalves-Araujo, R.; Stedmon, C.A.; Heim, B.; Dubinenkov, I.; Kraberg, A.; Moiseev, D.; Bracher, A. From Fresh to Marine Waters: Characterization and Fate of Dissolved Organic Matter in the Lena River Delta Region, Siberia. Front. Mar. Sci. 2015, 2, 108. [CrossRef]

47. Bauch, D.; Dmitrenko, I.A.; Wegner, C.; Hölemann, J.; Kirillov, S.A.; Timokhov, L.A.; Kassens, H. Exchange of Laptev Sea and Arctic Ocean halocline waters in response to atmospheric forcing. J. Geophys. Res. Space Phys. 2009, 114, C05008. [CrossRef]

48. Osadchiev, A.; Medvedev, I.; Shchuka, S.; Kulikov, M.; Spivak, E.; Pisareva, M.; Semiletov, I. Influence of estuarine tidal mixing on structure and spatial scales of large river plumes. Ocean Sci. 2020, 16, 781-798. [CrossRef]

49. Vetrov, A.; Romankevich, E.; Romankevich, E.A. Carbon Cycle in the Russian Arctic Seas; Springer Science \& Business Media: Berlin, Germany, 2004.

50. Alling, V.; Sanchez-Garcia, L.; Porcelli, D.; Pugach, S.; Vonk, J.E.; Van Dongen, B.; Mörth, C.-M.; Anderson, L.G.; Sokolov, A.; Gustafsson, Ö.; et al. Nonconservative behavior of dissolved organic carbon across the Laptev and East Siberian seas. Glob. Biogeochem. Cycles 2010, 24. [CrossRef]

51. Stedmon, C.; Markager, S.; Kaas, H. Optical Properties and Signatures of Chromophoric Dissolved Organic Matter (CDOM) in Danish Coastal Waters. Estuar. Coast. Shelf Sci. 2000, 51, 267-278. [CrossRef]

52. Chin, Y.-P.; Aiken, G.; O'Loughlin, E. Molecular Weight, Polydispersity, and Spectroscopic Properties of Aquatic Humic Substances. Environ. Sci. Technol. 1994, 28, 1853-1858. [CrossRef]

53. Lee, M.-H.; Osburn, C.L.; Shin, K.-H.; Hur, J. New insight into the applicability of spectroscopic indices for dissolved organic matter (DOM) source discrimination in aquatic systems affected by biogeochemical processes. Water Res. 2018, 147, 164-176. [CrossRef] [PubMed]

54. Allard, B.; Borén, H.; Pettersson, C.; Zhang, G. Degradation of humic substances by UV irradiation. Environ. Int. 1994, 20 , 97-101. [CrossRef]

55. Pavlov, A.K.; Granskog, M.A.; Stedmon, C.A.; Ivanov, B.V.; Hudson, S.R.; Falk-Petersen, S. Contrasting optical properties of surface waters across the Fram Strait and its potential biological implications. J. Mar. Syst. 2015, 143, 62-72. [CrossRef]

56. Granskog, M.A.; Pavlov, A.K.; Sagan, S.; Kowalczuk, P.; Raczkowska, A.; Stedmon, C.A. Effect of sea-ice melt on inherent optical properties and vertical distribution of solar radiant heating in Arctic surface waters. J. Geophys. Res. Ocean. 2015, 120, 7028-7039. [CrossRef]

57. Pugach, S.P.; Pipko, I.I.; Shakhova, N.E.; Shirshin, E.A.; Perminova, I.V.; Gustafsson, Ö.; Bondur, V.G.; Ruban, A.S.; Semiletov, I.P. Dissolved organic matter and its optical characteristics in the Laptev and East Siberian seas: Spatial distribution and interannual variability (2003-2011). Ocean Sci. 2018, 14, 87-103. [CrossRef]

58. Walker, S.A.; Amon, R.M.W.; Stedmon, C.A. Variations in high-latitude riverine fluorescent dissolved organic matter: A comparison of large Arctic rivers. J. Geophys. Res. Biogeosci. 2013, 118, 1689-1702. [CrossRef]

59. Stedmon, C.A.; Markager, S. The optics of chromophoric dissolved organic matter (CDOM) in the Greenland Sea: An algorithm for differentiation between marine and terrestrially derived organic matter. Limnol. Oceanogr. 2001, 46, 2087-2093. [CrossRef]

60. Kitidis, V.; Stubbins, A.P.; Uher, G.; Goddard, R.C.U.; Law, C.S.; Woodward, E.M.S. Variability of chromophoric organic matter in surface waters of the Atlantic Ocean. Deep. Sea Res. Part II Top. Stud. Oceanogr. 2006, 53, 1666-1684. [CrossRef]

61. Belyaev, N.A.; Peresypkin, V.I.; Ponyaev, M.S. The organic carbon in the water, the particulate matter, and the upper layer of the bottom sediments of the west Kara Sea. Oceanology 2010, 50, 706-715. [CrossRef]

62. Belyaev, N.A.; Ponyaev, M.S.; Kiriutin, A.M. Organic carbon in water, particulate matter, and upper layer of bottom sediments of the central part of the Kara Sea. Oceanology 2015, 55, 508-520. [CrossRef]

63. Meon, B.; Amon, R. Heterotrophic bacterial activity and fluxes of dissolved free amino acids and glucose in the Arctic rivers Ob, Yenisei and the adjacent Kara Sea. Aquat. Microb. Ecol. 2004, 37, 121-135. [CrossRef]

64. Cauwet, G.; Sidorov, I. The biogeochemistry of Lena River: Organic carbon and nutrients distribution. Mar. Chem. 1996, 53, 211-227. [CrossRef]

65. Fouest, V.L.; Babin, M.; Tremblay, J.É. The fate of riverine nutrients on Arctic shelves. Biogeosciences 2013, 10, 3661-3677. [CrossRef]

66. Lara, R.J.; Rachold, V.; Kattner, G.; Hubberten, H.W.; Guggenberger, G.; Skoog, A.; Thomas, D.N. Dissolved organic matter and nutrients in the Lena River, Siberian Arctic: Characteristics and distribution. Mar. Chem. 1998, 59, 301-309. [CrossRef] 
67. Lobbes, J.M.; Fitznar, H.P.; Kattner, G. Biogeochemical characteristics of dissolved and particulate organic matter in Russian rivers entering the Arctic Ocean. Geochim. Et Cosmochim. Acta 2000, 64, 2973-2983. [CrossRef]

68. Juhls, B.; Stedmon, C.A.; Morgenstern, A.; Meyer, H.; Hölemann, J.; Heim, B.; Povazhnyi, V.; Overduin, P.P. Identifying Drivers of Seasonality in Lena River Biogeochemistry and Dissolved Organic Matter Fluxes. Front. Environ. Sci. 2020, 8, 53. [CrossRef]

69. Organelli, E.; Claustre, H. Small Phytoplankton Shapes Colored Dissolved Organic Matter Dynamics in the North Atlantic Subtropical Gyre. Geophys. Res. Lett. 2019, 46, 12183-12191. [CrossRef] [PubMed]

70. Stedmon, C.A.; Markager, S. Tracing the production and degradation of autochthonous fractions of dissolved organic matter by fluorescence analysis. Limnol. Oceanogr. 2005, 50, 1415-1426. [CrossRef]

71. Semiletov, I.; Dudarev, O.; Luchin, V.; Charkin, A.; Shin, K.H.; Tanaka, N. The East Siberian Sea as a transition zone between Pacific-derived waters and Arctic shelf waters. Geophys. Res. Lett. 2005, 32, L10614. [CrossRef]

72. Spencer, R.G.; Aiken, G.R.; Butler, K.D.; Dornblaser, M.M.; Striegl, R.G.; Hernes, P.J. Utilizing chromophoric dissolved organic matter measurements to derive export and reactivity of dissolved organic carbon exported to the Arctic Ocean: A case study of the Yukon River, Alaska. Geophys. Res. Lett. 2009, 36, L06401. [CrossRef]

73. Kowalczuk, P.; Sagan, S.; Makarewicz, A.; Meler, J.; Borzycka, K.; Zabłocka, M.; Pavlov, A.K. Bio-optical properties of surface waters in the Atlantic Water inflow region off Spitsbergen (Arctic Ocean). J. Geophys. Res. Ocean. 2019, 124, 1964-1987. [CrossRef]

74. Bricaud, A.; Morel, A.; Babin, M.; Allali, K.; Claustre, H. Variations of light absorption by suspended particles with chlorophyll a concentration in oceanic (case 1) waters: Analysis and implications for bio-optical models. J. Geophys. Res. Ocean. 1998, 103, 31033-31044. [CrossRef]

75. Gonçalves-Araujo, R.; Röttgers, R.; Haraguchi, L.; Brandini, F.P. Hydrography-driven variability of optically active constituents of water in the South Brazilian Bight: Biogeochemical implications. Front. Mar. Sci. 2019, 6, 716. [CrossRef]

76. Sukhanova, I.N.; Flint, M.V.; Fedorov, A.V.; Sakharova, E.G.; Artemyev, V.A.; Makkaveev, P.N.; Nedospasov, A.A. Phytoplankton of the Khatanga Bay, Shelf and Continental Slope of the Western Laptev Sea. Oceanology 2019, 59, 648-657. [CrossRef]

77. Burenkov, V.I.; Goldin, Y.A.; Artem'Ev, V.A.; Sheberstov, S.V. Optical characteristics of the Kara Sea derived from shipborne and satellite data. Oceanology 2010, 50, 675-687. [CrossRef]

78. Vazyulya, S.V.; Kopelevich, O.V.; Sheberstov, S.V.; Artemiev, V.A. Satellite estimation of the coefficients of CDOM absorption and diffuse attenuation in the White and Kara seas. Curr. Probl. Remote Sens. Earth Space 2014, 11, 31-41. 